\title{
Application of Optical Quality Control Technologies in the Dairy Industry: An Overview
}

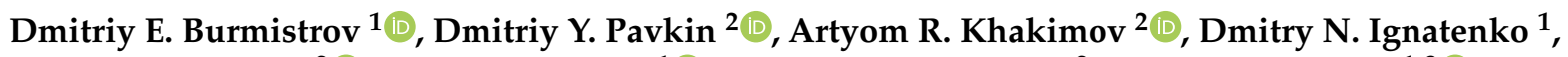 \\ Evgeniy A. Nikitin ${ }^{2}{ }^{(1)}$, Vasily N. Lednev ${ }^{1}{ }^{(}$, Yakov P. Lobachevsky ${ }^{2}$, Sergey V. Gudkov ${ }^{1,3}{ }^{(1)}$ \\ and Andrei V. Zvyagin $3,4,5, *$ (D) \\ 1 Prokhorov General Physics Institute of the Russian Academy of Sciences, Vavilova Str. 38, \\ 119991 Moscow, Russia; dmitriiburmistroff@gmail.com (D.E.B.); dmitriyek13104@yandex.ru (D.N.I.); \\ lednev@kapella.gpi.ru (V.N.L.); S_makariy@rambler.ru (S.V.G.) \\ 2 Federal State Budgetary Scientific Institution "Federal Scientific Agroengineering Center VIM", 1st Institutsky \\ Proezd 5, 109428 Moscow, Russia; dimqaqa@mail.ru (D.Y.P.); arty.hv@gmail.com (A.R.K.); \\ evgeniy.nicks@yandex.ru (E.A.N.); lobachevsky@yandex.ru (Y.P.L.) \\ 3 The Institute of Biology and Biomedicine, Lobachevsky State University of Nizhni Novgorod, \\ 603950 Nizhni Novgorod, Russia \\ 4 MQ Photonics Centre, Macquarie University, Sydney 2109, Australia \\ 5 Center of Biomedical Engineering, Sechenov University, 8 Trubetskaya Str., 119991 Moscow, Russia \\ * Correspondence: andrei.zvyagin@mq.edu.au
}

check for updates

Citation: Burmistrov, D.E.; Pavkin D.Y.; Khakimov, A.R.; Ignatenko, D.N.; Nikitin, E.A.; Lednev, V.N.; Lobachevsky, Y.P.; Gudkov, S.V.; Zvyagin, A.V. Application of Optical Quality Control Technologies in the Dairy Industry: An Overview. Photonics 2021, 8, 551. https:// doi.org/10.3390/photonics 8120551

Received: 22 October 2021 Accepted: 30 November 2021 Published: 3 December 2021

Publisher's Note: MDPI stays neutral with regard to jurisdictional claims in published maps and institutional affiliations.

Copyright: (c) 2021 by the authors. Licensee MDPI, Basel, Switzerland. This article is an open access article distributed under the terms and conditions of the Creative Commons Attribution (CC BY) license (https:// creativecommons.org/licenses/by/ $4.0 /)$.

\begin{abstract}
Sustainable development of the agricultural industry, in particular, the production of milk and feed for farm animals, requires accurate, fast, and non-invasive diagnostic tools. Currently, there is a rapid development of a number of analytical methods and approaches that meet these requirements. Infrared spectrometry in the near and mid-IR range is especially widespread. Progress has been made not only in the physical methods of carrying out measurements, but significant advances have also been achieved in the development of mathematical processing of the received signals. This review is devoted to the comparison of modern methods and devices used to control the quality of milk and feed for farm animals.
\end{abstract}

Keywords: optical diagnostics; analyzer; infrared spectroscopy; analysis of milk; analysis of feed; NIRS; MIRS

\section{Introduction}

Milk, as well as food products made from it (cottage cheese, cheese, yoghurts, etc.), are important elements of the human diet [1-3]. As is well known, the volume of consumed dairy products over the past decades has grown significantly [4,5]. In 2015, 497 million metric tons of cow milk was produced worldwide; by 2020, that figure had risen to around 532 million metric tons [6]. The constant increase in the consumption of milk and milk-containing food products requires the improvement of the methods of express control of the composition and quality of the milk produced. It is difficult to imagine a modern farm without automated solutions such as vacuum milking machines, automatic feeders, etc. To ensure product quality control, farms are increasingly using high-tech express analysis systems, which are gradually replacing the classic, expensive invasive chemical methods. However, chemical analysis methods still dominate the manufacturing environment, although they cannot provide the required online analysis. Among hightech modern methods, analyzers based on optical spectroscopy in both reflection [7] and absorption [8] modes are especially widespread and very popular in agriculture. In particular, the use of infrared spectroscopy in the visible (Vis) $400-800 \mathrm{~nm}$, near infrared (NIRS) 800-2500 nm, and mid-infrared (MIRS) 2500-15,000 nm ranges, as well as their combination, allows one to quickly and contactlessly assess the composition products and adjust the production process. Spectroscopic methods are widely used in agriculture 
for various purposes, such as: obtaining information on the composition of products [9], fertilizer content, the composition of the feed base for animals $[10,11]$, the composition of the soil [12], and the level of ripeness of the crop [13]. The most important advantage of modern optical analyzers used on the farm is their portability against the background of high accuracy, the speed of data, acquisition, and non-invasiveness. The quality and volume of dairy products produced depend on the composition and balance of the feed consumed by animals. In this regard, special attention is paid to the control of feed for farm animals. Of great interest is the use of the so-called remote sensing of pastures and fields with forage crops using unmanned and manned aerial vehicles. The creation of maps based on the obtained data allows for the predicting of changes in soil composition and for optimizing fertilization. The development of real-time monitoring tools for the composition of milk produced in production is also an extremely demanded task. Unfortunately, most milk analyzers are stationary and require preliminary preparation of the analyzed sample. Stationarity leads to a time delay between the receipt of the object under study and its analysis. Sample preparation affects the accuracy of the analysis due to the use of reagents, conservation, or freezing of the sample. The use of optical analyzers allows one to solve these problems and provide a quick adjustment to the production process. In this review, we consider the main spectral methods used in modern livestock farming. The focus of the review is aimed at comparing various analysis methods, instruments, and their prototypes operating in the visible, near, and middle infrared regions.

\section{Variety of Optical Techniques Used in Agricultural Applications}

Optical diagnostic methods are of great interest, since these methods have a high analysis speed, and also make it possible to diagnose an object by a non-contact method. All optical methods of analysis can be divided into two main categories: non-spectral and spectral (Figure 1). Using spectral methods, the spectrum of interaction of the object under study with electromagnetic radiation is recorded. The spectrum is the dependence of the radiation intensity on the wavelength, frequency, or wavenumber. Non-spectral methods are based on measuring the intensity of absorbed, emitted, reflected, or scattered light, as well as on the degree of its coherence. The main non-spectral methods include scatterometry (measurement of the specific effective scattering area), reflectometry (measurement of reflection loss), and refractometry (measurement of the refractive index). Currently, spectral methods are more often used for analysis, such as: emission spectral analysis (based on the analysis of emission or absorption spectra of radiation), absorption spectroscopy (based on the study of absorption spectra of the test substance), as well as analysis of the Raman scattering spectra of a substance [14] and, finally, the luminescent method of analysis [15]. Absorption spectroscopy, or absorption and transmission spectroscopy, makes it possible to simultaneously obtain the qualitative and quantitative composition of the object under study, and also provides information on the chemical nature of the substance. This method of analysis is characterized by high speed, high sensitivity, and the ability to analyze substances in all states of aggregation. The location of the "bands" in the obtained absorption spectrum carries information about the qualitative composition of the sample, and the intensity of the bands carries information about the concentration of the corresponding component [16]. A commonly used method for diagnosing biological objects, in particular, liquids (milk, blood, etc.), is optical spectroscopy in the near and far infrared region (MIRS and NIRS). MIR spectroscopy allows for the identification of vibrational transitions and covers the spectral range from 2500 to $50,000 \mathrm{~nm}\left(4000-200 \mathrm{~cm}^{-1}\right)$ [17]. Spectroscopy in the near infrared range (NIR; $800-2500 \mathrm{~nm} ; 10,000-4000 \mathrm{~cm}^{-1}$ ) allows one to obtain information about the molecules of the sample under study by measuring absorption bands resulting from overtones and combined excitations [18]. All molecules containing a hydrogen atom have a measurable spectrum in the near IR region, which contributes to the fact that a wider range of organic materials is suitable for analysis in the near IR range than for analysis in the mid IR range [17]. 


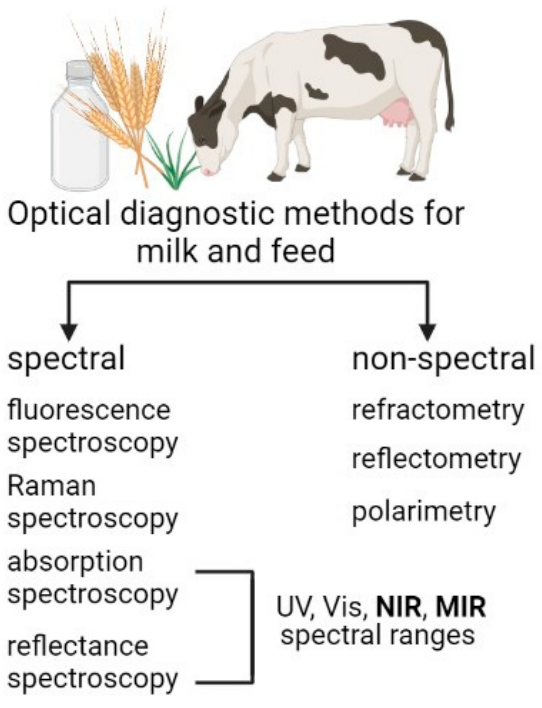

Figure 1. The main methods of optical diagnostics used on dairy farms to analyze the composition of milk and feed.

In a recent review by Evangelista et al. [19], a wide range of agricultural applications of NIR spectroscopy were reported. In particular, modern solutions were considered for assessing the digestibility of the diet by analyzing the chemical-physical composition of raw materials in the general mixed diet and analyzing the chemical composition of slurry and manure. The possibility of using this method for the "online analysis" of milk in the milking parlor was also considered [19].

Depending on the sample under study, the NIRS and MIRS method can be applied in two modes: absorption (transmission) and reflection. When measuring transmission, the detector is placed behind the test sample, which is illuminated by an IR source. The sample should be partially transparent. This type of analysis is often impossible with massive and optically opaque samples. However, when thin samples are available, the transmission imaging mode provides ease of spectra interpretation, improves signal-tonoise ratio, reduces spectral distortion, and increases the correlation between molecular structures and spectral characteristics [20]. To work with plant objects in the transmission mode, preliminary preparation of the sample is carried out; however, this can lead to a change in the native composition and structure of the object. In this regard, for the analysis of plant objects with low transparency, IR spectroscopy in the reflection mode is often used [21-23]. In this approach, the detector and source are placed on the side of the sample to register the signal reflected by the object.

Fourier transform infrared spectroscopy (FTIR) has become especially popular for use in the analysis of biological objects. In a Fourier spectrometer, infrared light passes through the interferometer and then through the sample (or vice versa). The FTIR spectrometer simultaneously collects high-resolution spectral data over a wide spectral range. By using the Fourier transform, a more precise analysis of the composition of the sample becomes possible. This gives a significant advantage over a dispersive spectrometer, which measures the intensity in a narrow wavelength range [24]. Thus, the overwhelming majority of modern commercial IR spectrometers operate with Fourier transform, providing accurate analysis with a wide range of investigated components [25]. 


\section{Presentation of Tabular Data}

We analyzed modern literature sources that considered various approaches to assess the composition of milk using optical methods. The data are presented in the form of tables. For milk analysis methods, 50 sources were analyzed. For the analysis of feed, 25 literature sources. When compiling tables (see Tables 1 and 3), we searched for publications over the past 10 years in scientific search systems (machine search), such as Scopus, Web of Science, Google Scholar. When searching for articles, we used sorting by publication year. The search used tags such as "infrared spectroscopy", "milk analysis", "feed analysis", "optical methods", "MIRs", "NIRs", "analyzer", "forage", "agriculture", and their combinations. It is important to note that we did not independently select any separate articles but used only publications offered by the search service.

\section{Using Optical Methods for Analyzing the Composition of Milk}

Production control of the quality of milk, as well as products made from it, is an important problem in the modern dairy industry. An important task is to create technological solutions for the express analysis of raw milk during milking, without a time delay. Currently, a number of promising optical methods for diagnosing the composition of milk are proposed, including measuring optical density [26], the method of luminescence spectroscopy $[27,28]$, methods of light scattering (scatterometry) [29,30], as well as the method of IR spectroscopy $[9,18]$. 
Table 1. Main characteristics of optical methods and devices used to assess the quality of milk.

\begin{tabular}{|c|c|c|c|c|c|c|c|c|c|}
\hline $\mathbf{N}$ & Analyzer Characteristics & Type $(\mathrm{C} / \mathrm{I})$ * & $\begin{array}{l}\text { Analysis } \\
\text { Method }\end{array}$ & $\begin{array}{c}\text { Spectral Range, } \\
\text { nm }\end{array}$ & Flow/Intake & $\begin{array}{c}\text { The } \\
\text { Investigated } \\
\text { Components of } \\
\text { Milk }\end{array}$ & Method Advantages & Prediction Value & Ref. \\
\hline 1 & $\begin{array}{c}\text { Milkoscan FT + } \\
\text { (Foss-Electric A/S, } \\
\text { Hillerød, Denmark) }\end{array}$ & I & $\begin{array}{c}\text { NIR- } \\
\text { spectroscopy }\end{array}$ & $851-1649$ & intake & $\begin{array}{r}\text { fat, protein, } \\
\text { lactose, urea }\end{array}$ & $\begin{array}{l}\text { sufficient and } \\
\text { adequate prediction } \\
\text { accuracy with regard } \\
\text { to fat and protein } \\
\text { content in milk was } \\
\text { achieved }\end{array}$ & $\begin{array}{l}\mathrm{R}^{2} \text { were } 0.998,0.94, \\
\text { and } 0.73 \text { for fat, } \\
\text { protein, lactose; } 0.31 \\
\text { for urea, respectively }\end{array}$ & {$[31]$} \\
\hline 2 & $\begin{array}{l}\text { installation: } 18 \text { channel } \\
\text { multispectral } \\
\text { photosensor module and } \\
\text { miniature halogen lamp }\end{array}$ & I & $\begin{array}{c}\text { Vis/NIR- } \\
\text { spectroscopy }\end{array}$ & $410-940$ & intake & $\begin{array}{l}\text { fat, protein, } \\
\text { lactose }\end{array}$ & $\begin{array}{l}\text { high measurement } \\
\text { speed, } \\
\text { cost-effectiveness of } \\
\text { the device and } \\
\text { operational efficiency }\end{array}$ & $\begin{array}{l}\text { RPD increased for fat } \\
\text { after homogenization } \\
\text { from } 2.34 \text { to } 3.48 \text {; for } \\
\text { total solids from } 2.06 \\
\text { to } 2.14\end{array}$ & {$[32]$} \\
\hline 3 & Xethru X4 sensor & $\mathrm{C}$ & $\begin{array}{l}\text { wideband } \\
\text { dielectric } \\
\text { spectroscopy } \\
\text { (WBDS) }\end{array}$ & $1300-3000$ & intake & fat & $\begin{array}{l}\text { high precision and } \\
\text { non-contact } \\
\text { application }\end{array}$ & - & {$[33]$} \\
\hline 4 & $\begin{array}{c}\text { MilkoScan FT + (Foss } \\
\text { Electric A/S) }\end{array}$ & $\mathrm{C}$ & $\begin{array}{c}\text { MIR- } \\
\text { spectroscopy }\end{array}$ & $1300-3000$ & intake & $\begin{array}{l}\text { fat, protein, } \\
\text { lactose dry } \\
\text { matter, as well } \\
\text { as the number } \\
\text { of somatic cells }\end{array}$ & - & - & {$[34]$} \\
\hline 5 & $\begin{array}{l}\text { five in-line, two-stage } \\
\text { MIR homogenizers (Delta } \\
\text { Instruments) with } \\
\text { different homogenization } \\
\text { efficiency; LactoScope } \\
\text { FTIR Advanced (FTA) } \\
\text { milk analyzer equipped } \\
\text { with a BMX optical bench } \\
\text { (ABB Bomem, MO, } \\
\text { Canada) }\end{array}$ & $\mathrm{C}$ & $\begin{array}{c}\text { FT-MIR } \\
\text { spectroscopy }\end{array}$ & $1300-3000$ & flow & $\begin{array}{c}\text { fat, true protein, } \\
\text { anhydrous } \\
\text { lactose }\end{array}$ & $\begin{array}{l}\text { homogenization } \\
\text { efficiency influenced } \\
\text { the results of the } \\
\text { assessment of the } \\
\text { content of fat and } \\
\text { protein }\end{array}$ & - & {$[35]$} \\
\hline
\end{tabular}


Table 1. Cont.

\begin{tabular}{|c|c|c|c|c|c|c|c|c|c|}
\hline $\mathbf{N}$ & Analyzer Characteristics & Type $(\mathrm{C} / \mathrm{I})$ * & $\begin{array}{l}\text { Analysis } \\
\text { Method }\end{array}$ & $\begin{array}{l}\text { Spectral Range, } \\
\mathrm{nm}\end{array}$ & Flow/Intake & $\begin{array}{c}\text { The } \\
\text { Investigated } \\
\text { Components of } \\
\text { Milk }\end{array}$ & Method Advantages & Prediction Value & Ref. \\
\hline 6 & $\begin{array}{l}\text { MicroPhazir }{ }^{\mathrm{TM}} \mathrm{NIR} \\
\text { Spectrophotometer }\end{array}$ & $\mathrm{C}$ & $\begin{array}{c}\text { NIR- } \\
\text { spectroscopy }\end{array}$ & $1600-2400$ & flow & $\begin{array}{l}\text { fat, protein, } \\
\text { fat-free solids }\end{array}$ & $\begin{array}{l}\text { monitoring in } \\
\text { real-time, in-situ and } \\
\text { without pre-treatment } \\
\text { milk composition, } \\
\text { portability, the ability } \\
\text { to synchronize } \\
\text { between individual } \\
\text { devices }\end{array}$ & $\begin{array}{c}\mathrm{R}^{2} \text { for fat, protein, } \\
\text { fat-free solids were } \\
0.97,0.75,0.61 \\
\text { respectively }\end{array}$ & {$[36]$} \\
\hline 7 & $\begin{array}{l}\text { Spectral Analyzer } \\
\text { AS7262-AS7263 }\end{array}$ & I & $\begin{array}{c}\text { NIR- } \\
\text { spectroscopy }\end{array}$ & $960-1690$ & flow & $\begin{array}{l}\text { fat, protein, } \\
\text { lactose }\end{array}$ & $\begin{array}{c}\text { system can analyze } \\
\text { the milk of each } \\
\text { individual milking } \\
\text { session } \\
\text { autonomously; fast } \\
\text { online milk analysis, } \\
\text { using a real-time } \\
\text { prediction model }\end{array}$ & $\begin{array}{c}\mathrm{R}^{2}=0.989 \text { (fat), } 0.894 \\
\quad(\text { protein) and } 0.644 \\
\quad(\text { lactose })\end{array}$ & [37] \\
\hline 8 & $\begin{array}{c}\text { MilkoScan FT6000, (Foss, } \\
\text { Hillerod, Denmark) }\end{array}$ & $\mathrm{C}$ & $\begin{array}{c}\text { MIR- } \\
\text { spectroscopy }\end{array}$ & $\begin{array}{r}3359-3612 ; \\
5555-5938 \\
6222-10,799\end{array}$ & intake & $\begin{array}{l}\text { non-esterified } \\
\text { fatty acids } \\
\text { (NEFA) }\end{array}$ & $\begin{array}{l}\text { determination of the } \\
\text { content of } \\
\text { non-esterified fatty } \\
\text { acids (NEFA) in the } \\
\text { blood of cows using } \\
\text { MIR-IR spectroscopy } \\
\text { of milk, without } \\
\text { blood sampling }\end{array}$ & $\begin{array}{c}\mathrm{R}^{2} \text { values of } 0.613 \text { and } \\
0.502, \text { respectively }\end{array}$ & {$[38]$} \\
\hline 9 & $\begin{array}{l}\text { Portable IR spectrometer } \\
\text { MicroPHAZIR TM }\end{array}$ & $\mathrm{C}$ & $\begin{array}{c}\text { NIR- } \\
\text { spectroscopy }\end{array}$ & $1600-2400$ & intake & $\begin{array}{l}\text { protein, fat, } \\
\text { fat-free solids, } \\
\text { lactose }\end{array}$ & $\begin{array}{l}\text { real-time tracking of } \\
\text { quality control } \\
\text { parameters for an } \\
\text { individual sample }\end{array}$ & - & [39] \\
\hline
\end{tabular}


Table 1. Cont.

\begin{tabular}{|c|c|c|c|c|c|c|c|c|c|}
\hline $\mathbf{N}$ & Analyzer Characteristics & Type (C/I) * & $\begin{array}{l}\text { Analysis } \\
\text { Method }\end{array}$ & $\begin{array}{l}\text { Spectral Range, } \\
\text { nm }\end{array}$ & Flow/Intake & $\begin{array}{c}\text { The } \\
\text { Investigated } \\
\text { Components of } \\
\text { Milk }\end{array}$ & Method Advantages & Prediction Value & Ref. \\
\hline 10 & $\begin{array}{l}\text { MilkoScan Minor, (Foss, } \\
\text { Hillerød, Denmark) }\end{array}$ & C & $\begin{array}{c}\text { NIR- } \\
\text { spectroscopy }\end{array}$ & $400-900$ & intake & $\begin{array}{l}\text { fat, protein, total } \\
\text { solid, lactose }\end{array}$ & $\begin{array}{l}\text { the possibility of } \\
\text { using } \\
\text { NIR-spectroscopy to } \\
\text { assess the genetic } \\
\text { variability and } \\
\text { heredity of qualitative } \\
\text { traits of colostrum }\end{array}$ & - & {$[40]$} \\
\hline 11 & $\begin{array}{l}\text { Milko-Scan FT1 (Foss } \\
\text { Electric, Hillerød, } \\
\text { Denmark). }\end{array}$ & $\mathrm{C}$ & $\begin{array}{c}\text { FT-MIR } \\
\text { spectroscopy }\end{array}$ & $2000-10,800$ & intake & $\begin{array}{c}\text { fat, total protein, } \\
\text { casein, lactose, } \\
\text { total solids, } \\
\text { solids-not-fat }\end{array}$ & $\begin{array}{l}\text { precise definition of } \\
\text { milk components for } \\
\text { comparison of } \\
\text { different genetic } \\
\text { groups and breeds } \\
\text { of cows }\end{array}$ & $\begin{array}{l}\mathrm{R}^{2} \text { were } 0.99 \text { for fat, } \\
\text { protein, casein, total } \\
\text { solid; } 0.97 \text { for lactose; } \\
0.94 \text { for solids-not-fat }\end{array}$ & {$[41]$} \\
\hline 12 & $\begin{array}{c}\text { LactoScope } \\
\text { FTIR Advanced; five } \\
\text { different homogenizers }\end{array}$ & $\mathrm{C}$ & $\begin{array}{c}\text { FT-MIR } \\
\text { spectroscopy }\end{array}$ & $1300-3000$ & intake & fat & $\begin{array}{l}\text { predicting the particle } \\
\text { size of fat globules in } \\
\text { homogenized milk }\end{array}$ & - & [42] \\
\hline 13 & $\begin{array}{c}\text { MilkoScan FT } 120 \text { (FOSS, } \\
\text { Hillerød, Denmark; } \\
\text { Milcom Servis as, } \\
\text { (Prague, Czech Republic) }\end{array}$ & $\mathrm{C}$ & $\begin{array}{c}\text { MIR- } \\
\text { spectroscopy }\end{array}$ & $1300-3000$ & intake & $\begin{array}{l}\text { determination } \\
\text { of preservatives } \\
\text { content in milk }\end{array}$ & - & - & {$[43]$} \\
\hline 14 & $\begin{array}{l}\text { installation: probe with } \\
\text { eight fiber optic channels } \\
\text { with a diameter of } \\
200 \mu \mathrm{m} \text {, forming a } \\
\text { linear array }\end{array}$ & I & $\begin{array}{c}\text { Vis/NIR- } \\
\text { spectroscopy }\end{array}$ & $400-995$ & intake, flow & fat, total protein & $\begin{array}{l}\text { alternative to } \\
\text { full-scale scanning or } \\
\text { diode array } \\
\text { spectroscopy }\end{array}$ & $\begin{array}{l}\mathrm{R}^{2} \text { for fat } 0.97 \text {; for } \\
\text { protein } 0.84\end{array}$ & {$[44]$} \\
\hline
\end{tabular}


Table 1. Cont.

\begin{tabular}{|c|c|c|c|c|c|c|c|c|c|}
\hline $\mathbf{N}$ & Analyzer Characteristics & Type $(\mathrm{C} / \mathrm{I})$ * & $\begin{array}{l}\text { Analysis } \\
\text { Method }\end{array}$ & $\begin{array}{c}\text { Spectral Range, } \\
\mathrm{nm}\end{array}$ & Flow/Intake & $\begin{array}{c}\text { The } \\
\text { Investigated } \\
\text { Components of } \\
\text { Milk }\end{array}$ & Method Advantages & Prediction Value & Ref. \\
\hline 15 & $\begin{array}{l}\text { MilkoScan FT120 (Foss, } \\
\text { Hillerød, Denmark) }\end{array}$ & $\mathrm{C}$ & $\begin{array}{l}\text { Vis/NIR } \\
\text { spectroscopy } \\
\text { dispersion- } \\
\text { based }\end{array}$ & $400-1100$ & intake, flow & fat, total protein & $\begin{array}{l}\text { the generated PLS } \\
\text { regression models } \\
\text { were trained on a } \\
\text { very large set of milk } \\
\text { samples; the accuracy } \\
\text { of the resulting } \\
\text { models makes them } \\
\text { suitable for many } \\
\text { practical applications } \\
\text { in the dairy industry }\end{array}$ & $\begin{array}{l}\mathrm{R}^{2} \text { for fat was } 0.95 ; \text { for } \\
\text { protein was } 0.77 \text { (PLS) }\end{array}$ & [45] \\
\hline 16 & $\begin{array}{l}\text { NIR spectrometer } \\
\text { MP.0331.04, (Bruker Co., } \\
\text { Bremen, Germany) }\end{array}$ & $\mathrm{C}$ & $\begin{array}{c}\text { FT-NIR } \\
\text { spectroscopy }\end{array}$ & $833-2500$ & intake & $\begin{array}{l}\text { fat, } \\
\text { total protein }\end{array}$ & $\begin{array}{l}\text { PLSR-UVE-PLS } \\
\text { model had excellent } \\
\text { protein prediction for } \\
\text { non-homogenized } \\
\text { milk }\end{array}$ & $\begin{array}{l}\text { RPD when using the } \\
\text { PLCR model for } \\
\text { protein determination, } \\
\text { before } \\
\text { homogenization was } \\
\text { 2.22; after } 2.73\end{array}$ & {$[46]$} \\
\hline 17 & $\begin{array}{l}\text { Horiba LA-920; (Horiba } \\
\text { Instruments Inc., Irvine, } \\
\text { CA, USA) }\end{array}$ & $\mathrm{C}$ & $\begin{array}{l}\text { Laser } \\
\text { scatterometry, } \\
\text { Vis/NIR- } \\
\text { spectroscopy }\end{array}$ & $360-970$ & intake, flow & $\begin{array}{l}\text { fat, fatty acid } \\
\text { profile, protein, } \\
\text { lactose }\end{array}$ & $\begin{array}{l}\text { the device provides } \\
\text { the ability to take } \\
\text { multiple samples } \\
\text { during milking } \\
\text { without losing } \\
\text { vacuum or } \\
\text { interrupting } \\
\text { intermediate milk } \\
\text { sampling }\end{array}$ & $\begin{array}{c}\mathrm{R}^{2} \text { for fat, protein, } \\
\text { lactose was } 0.94 ; 0.92 ; \\
0.84\end{array}$ & [47] \\
\hline 18 & $\begin{array}{l}\text { IR spectrophotometer } \\
\text { with a diode matrix in the } \\
\text { diffuse transmission } \\
\text { mode; glass cavity with } \\
\text { an internal path length of } \\
4 \mathrm{~mm}\end{array}$ & I & $\begin{array}{c}\text { NIR- } \\
\text { spectroscopy }\end{array}$ & $400-1100$ & intake & fat, total protein & $\begin{array}{l}\text { variety and relative } \\
\text { cheapness of } \\
\text { components, high } \\
\text { design flexibility }\end{array}$ & $\begin{array}{c}\mathrm{R}^{2}=0.9 \text { for fat and } \\
\text { protein }\end{array}$ & [48] \\
\hline
\end{tabular}


Table 1. Cont.

\begin{tabular}{|c|c|c|c|c|c|c|c|c|c|}
\hline $\mathbf{N}$ & Analyzer Characteristics & Type $(\mathrm{C} / \mathrm{I})$ * & $\begin{array}{l}\text { Analysis } \\
\text { Method }\end{array}$ & $\begin{array}{l}\text { Spectral Range, } \\
\mathrm{nm}\end{array}$ & Flow/Intake & $\begin{array}{c}\text { The } \\
\text { Investigated } \\
\text { Components of } \\
\text { Milk }\end{array}$ & Method Advantages & Prediction Value & Ref. \\
\hline 19 & $\begin{array}{l}\text { TIDAS E oT J\&M } \\
\text { Analytik AG, Esslingen, } \\
\text { Germany) in diffuse } \\
\text { transmission mode } \\
\text { through a } 4 \text { mm cuvette }\end{array}$ & $\mathrm{C}$ & $\begin{array}{c}\text { Vis/NIR- } \\
\text { spectroscopy }\end{array}$ & $400-1100$ & intake & fat, protein & $\begin{array}{l}\text { the method shows the } \\
\text { influence of the size } \\
\text { distribution of fat } \\
\text { globules on the } \\
\text { diffuse transmission } \\
\text { spectra }\end{array}$ & - & [49] \\
\hline 20 & $\begin{array}{c}\text { FTLA } 2000 \text { (ABB, } \\
\text { Saint-Laurent, QC, } \\
\text { Canada) with thermostat } \\
\text { and light transmission } \\
\text { control }\end{array}$ & C & $\begin{array}{c}\text { FT-NIR- } \\
\text { spectroscopy }\end{array}$ & $780-2500$ & intake & $\begin{array}{c}\text { Escherichia coli., } \\
\text { Pseudomonas } \\
\text { aeruginosa }\end{array}$ & $\begin{array}{l}\text { NIRS can be used to } \\
\text { detect and quantify } \\
\text { pathogenic bacteria } \\
\text { and bacteria that } \\
\text { cause milk spoilage }\end{array}$ & $\begin{array}{l}\mathrm{R}^{2} \text { for E. coli was } 0.94 \\
\text { for } P \text {. aeruginosa } 0.60\end{array}$ & {$[50]$} \\
\hline 21 & $\begin{array}{l}\text { testing data from two } \\
\text { anonymous MIR } \\
\text { instruments }\end{array}$ & I & $\begin{array}{c}\text { MIR- } \\
\text { spectroscopy }\end{array}$ & $1300-3000$ & flow & $\begin{array}{l}\text { fat, protein, dry } \\
\text { matter }\end{array}$ & $\begin{array}{l}\text { a statistical approach } \\
\text { has been developed } \\
\text { to determine the } \\
\text { differences from the } \\
\text { obtained values } \\
\text { between the two } \\
\text { instruments }\end{array}$ & - & {$[51]$} \\
\hline 22 & $\begin{array}{l}\text { MilkoScan FT-120, Foss } \\
\text { (Foss A/S, Hillerød, } \\
\text { Denmark); Near } \\
\text { Infra-Red Multipurpose } \\
\text { Analyzer (MPA) Bruker } \\
\text { Optik Gmbh (Ettlingen, } \\
\text { Germany) }\end{array}$ & $\mathrm{C}$ & $\begin{array}{l}\text { FT-MIR and } \\
\text { FT-NIR } \\
\text { spectroscopy }\end{array}$ & $\begin{array}{c}800-2500 \\
2500-15,000\end{array}$ & intake & $\begin{array}{l}\text { lactose, protein, } \\
\text { fat, total solid }\end{array}$ & $\begin{array}{l}\text { near and mid-infrared } \\
\text { spectroscopy methods } \\
\text { are both valuable for } \\
\text { raw milk analysis }\end{array}$ & $\begin{array}{c}\text { Correlation } \\
\text { coefficient } \geq 0.96 \text { for } \\
\text { protein, } r \geq 0.99 \text { for } \\
\text { fat, } r=0.82 \text { for lactose; } \\
r=0.90 \text { for total solid }\end{array}$ & {$[52]$} \\
\hline
\end{tabular}


Table 1. Cont.

\begin{tabular}{|c|c|c|c|c|c|c|c|c|c|}
\hline $\mathbf{N}$ & Analyzer Characteristics & Type $(\mathrm{C} / \mathrm{I})$ * & $\begin{array}{c}\text { Analysis } \\
\text { Method }\end{array}$ & $\begin{array}{c}\text { Spectral Range, } \\
\text { nm }\end{array}$ & Flow/Intake & $\begin{array}{c}\text { The } \\
\text { Investigated } \\
\text { Components of } \\
\text { Milk }\end{array}$ & Method Advantages & Prediction Value & Ref. \\
\hline 23 & $\begin{array}{l}\text { installation combining } \\
\text { measurements of } \\
\text { transmission, scattering } \\
\text { and fluorescence spectra } \\
\text { of milk; halogen and } \\
\text { deuterium lamps, optical } \\
\text { fiber system, AvaSpec } \\
2048 \text { spectrometer with } 8 \\
\text { nm resolution }\end{array}$ & I & $\begin{array}{c}\text { Vis/NIR- } \\
\text { spectroscopy }\end{array}$ & $300-1100$ & intake & $\begin{array}{l}\text { fat, protein, } \\
\text { carbohydrates, } \\
\text { minerals, } \\
\text { calories }\end{array}$ & $\begin{array}{l}\text { fluorescence and } \\
\text { scattering spectra of } \\
\text { milk can be used for } \\
\text { the identification of } \\
\text { different producers of } \\
\text { milk and for } \\
\text { obtaining information } \\
\text { about milk chemical } \\
\text { composition }\end{array}$ & - & [53] \\
\hline 24 & $\begin{array}{l}\text { Milkoscan (Foss Electric, } \\
\text { Hillerod, Denmark) }\end{array}$ & I & $\begin{array}{c}\text { NIR- } \\
\text { spectroscopy }\end{array}$ & $700-1050$ & flow & $\begin{array}{c}\text { fat, protein, } \\
\text { lactose, somatic } \\
\text { cells }\end{array}$ & $\begin{array}{l}\text { the NIR spectroscopic } \\
\text { sensing system } \\
\text { developed in this } \\
\text { study can be used for } \\
\text { online real-time } \\
\text { monitoring of fat, } \\
\text { protein, lactose and } \\
\text { somatic cells }\end{array}$ & $\begin{array}{c}\mathrm{R}^{2} \text { were } 0.98 ; 0.72 ; \\
0.54 ; 0.63 \text { for fat, } \\
\text { protein, lactose, } \\
\text { somatic cells, } \\
\text { respectively }\end{array}$ & {$[54]$} \\
\hline 25 & $\begin{array}{l}\text { AfiLab (Afimilk, Kibbutz } \\
\text { Afikim, Israel); Bentley } \\
2000 \text { (Bentley Instruments } \\
\text { Inc., Chaska, MN, USA) }\end{array}$ & C & $\begin{array}{l}\text { MIR- } \\
\text { spectroscopy; } \\
\text { NIR- } \\
\text { spectroscopy }\end{array}$ & $\begin{array}{c}300-950 \\
1300-3000\end{array}$ & intake, flow & $\begin{array}{l}\text { fat, anhydrous } \\
\text { lactose, protein, } \\
\text { total solids } \\
\text { content }\end{array}$ & $\begin{array}{l}\text { AfiLab real-time milk } \\
\text { analyzers can be } \\
\text { useful for assessing } \\
\text { the content of milk } \\
\text { components }\end{array}$ & - & [55] \\
\hline 26 & $\begin{array}{l}\text { Milkoscan FT + (Foss } \\
\text { A/S, Hillerod, Denmark), } \\
\text { reflection/transmission } \\
\text { mode; }\end{array}$ & $\mathrm{C}$ & $\begin{array}{l}\text { MIR- } \\
\text { spectroscopy; } \\
\text { NIR- } \\
\text { spectroscopy }\end{array}$ & $\begin{array}{c}400-1000 \\
11,000-2500\end{array}$ & intake & $\begin{array}{c}\text { fat, crude } \\
\text { protein, lactose, } \\
\text { urea }\end{array}$ & $\begin{array}{l}\text { transmission } \\
\text { spectroscopy can be } \\
\text { used to predict the } \\
\text { three main } \\
\text { components of milk, } \\
\text { but with less accuracy } \\
\text { for fat and crude } \\
\text { protein than in } \\
\text { reflection mode }\end{array}$ & $\begin{array}{l}\text { reflection: } \mathrm{R}^{2} \text { for fat } \\
\text { and protein was } \\
>0.95 \text {; for lactose was } \\
<0.75 \text {; transmission: } \\
\mathrm{R}^{2} \text { for fat and protein } \\
\text { was >0.9; for lactose } \\
\text { was } 0.88 \text {; }\end{array}$ & [7] \\
\hline
\end{tabular}


Table 1. Cont.

\begin{tabular}{|c|c|c|c|c|c|c|c|c|c|}
\hline $\mathbf{N}$ & Analyzer Characteristics & Type $(\mathrm{C} / \mathrm{I})$ * & $\begin{array}{l}\text { Analysis } \\
\text { Method }\end{array}$ & $\begin{array}{l}\text { Spectral Range, } \\
\mathrm{nm}\end{array}$ & Flow/Intake & $\begin{array}{c}\text { The } \\
\text { Investigated } \\
\text { Components of } \\
\text { Milk }\end{array}$ & Method Advantages & Prediction Value & Ref. \\
\hline 27 & $\begin{array}{c}\text { MilkoScan FT6000 (Foss } \\
\text { Electronic A/S) }\end{array}$ & $\mathrm{C}$ & $\begin{array}{c}\text { FT-MIR- } \\
\text { spectroscopy }\end{array}$ & $2000-12,000$ & intake & $\begin{array}{l}\text { fat, protein, } \\
\text { lactose }\end{array}$ & $\begin{array}{l}\text { using modern } \\
\text { statistical machine } \\
\text { learning methods to } \\
\text { predict features based } \\
\text { on mid-infrared } \\
\text { spectroscopy can } \\
\text { improve prediction } \\
\text { accuracy }\end{array}$ & $\begin{array}{c}\mathrm{R}^{2} \text { were } 0.65 \text { for } \mathrm{pH} ; \\
0.5 \text { for rennet } \\
\text { coagulation time; } \\
0.2-0.5 \text { for protein; }<1 \\
\text { for casein micelle size }\end{array}$ & {$[56]$} \\
\hline 28 & $\begin{array}{c}\text { MilkoScan FT6000 (Foss } \\
\text { Electric A/S, Hillerod, } \\
\text { Denmark) }\end{array}$ & $\mathrm{C}$ & $\begin{array}{c}\text { MIR- } \\
\text { spectroscopy }\end{array}$ & $2000-15,000$ & intake & $\begin{array}{c}\text { fatty acid } \\
\text { composition, } \\
\text { protein, } \\
\text { lactoferrin, } \mathrm{Ca}, \mathrm{P}, \\
\mathrm{Mg}, \mathrm{K}\end{array}$ & $\begin{array}{l}\text { the use of various } \\
\text { models for forecasting } \\
\text { the composition }\end{array}$ & - & [57] \\
\hline 29 & $\begin{array}{c}\text { MilkoScan FT6000 (Foss } \\
\text { Electric A/S, Hillerod, } \\
\text { Denmark) }\end{array}$ & $\mathrm{C}$ & $\begin{array}{c}\text { MIR- } \\
\text { spectroscopy }\end{array}$ & $2000-15,000$ & intake & $\begin{array}{l}\text { fatty acid profile, } \\
\text { protein } \\
\text { composition, } \\
\text { lactoferrin, } \\
\text { concentration of } \\
\text { basic minerals }\end{array}$ & $\begin{array}{l}\text { high accuracy of the } \\
\text { profile of fatty acids } \\
\text { in milk }\end{array}$ & $\begin{array}{l}\text { RPD were } 1.8-2.0 \text { for } \\
\text { fatty acids; } 1.6 \text { for } \\
\text { protein; } 1.8 \text { for fat; } \\
1.3-1.4 \text { for minerals }\end{array}$ & {$[58]$} \\
\hline 30 & $\begin{array}{l}\text { Milko-Scan FT120 (Foss } \\
\text { Electric A/S, Denmark) }\end{array}$ & $\mathrm{C}$ & $\begin{array}{c}\text { FT-MIR } \\
\text { spectroscopy }\end{array}$ & $2500-12,000$ & intake & $\begin{array}{l}\text { total protein, } \\
\text { casein, milk } \\
\text { protein } \\
\text { composition, } \\
\beta \text {-lactoglobulin, } \\
\text { glycosylated } \mathrm{k}- \\
\text { casein, whey } \\
\text { protein }\end{array}$ & $\begin{array}{l}\text { the use of FT-MIRS to } \\
\text { predict the detailed } \\
\text { protein composition } \\
\text { of milk }\end{array}$ & $\begin{array}{l}\text { RPD were } 2.2 \text { for } \\
\text { protein; } 2.07 \text { for } \\
\text { casein; } 1.6 \text { for whey } \\
\text { protein }\end{array}$ & [59] \\
\hline
\end{tabular}


Table 1. Cont.

\begin{tabular}{|c|c|c|c|c|c|c|c|c|c|}
\hline $\mathbf{N}$ & Analyzer Characteristics & Type $(\mathrm{C} / \mathrm{I})$ * & $\begin{array}{l}\text { Analysis } \\
\text { Method }\end{array}$ & $\begin{array}{l}\text { Spectral Range, } \\
\text { nm }\end{array}$ & Flow/Intake & $\begin{array}{c}\text { The } \\
\text { Investigated } \\
\text { Components of } \\
\text { Milk }\end{array}$ & Method Advantages & Prediction Value & Ref. \\
\hline 31 & $\begin{array}{l}\text { Optigraph (OPT; Ysebaert } \\
\text { SA, Frépillon, France); } \\
\text { MilkoScan FT6000 (Foss } \\
\text { Electric A/S, Hillerod, } \\
\text { Denmark); Fossomatic FC } \\
\text { (Foss Electric A/S) for } \\
\text { determining the presence } \\
\text { of somatic cells }\end{array}$ & $\mathrm{C}$ & $\begin{array}{c}\text { NIR- } \\
\text { spectroscopy; } \\
\text { MIR- } \\
\text { spectroscopy }\end{array}$ & $\begin{array}{c}2000-15,000 \\
350-1000\end{array}$ & intake & $\begin{array}{l}\text { fat, protein, } \\
\text { casein, lactose }\end{array}$ & $\begin{array}{l}\text { the optical method for } \\
\text { analyzing the } \\
\text { composition of milk is } \\
\text { a good alternative to } \\
\text { the mechanical } \\
\text { method }\end{array}$ & $\begin{array}{c}\text { correlation } \\
\text { coefficients for rennet } \\
\text { coagulation time was } \\
0.82 \text {; for curd-firming } \\
\text { time was } 0.49 \text {; curd } \\
\text { firmness at } 30 \text { min } \\
\text { was } 0.69 \text {; for curd } \\
\text { firmness at } 45 \text { min } \\
\text { was } 0.41\end{array}$ & {$[60]$} \\
\hline 32 & $\begin{array}{c}\text { MilkoScan FT } 6000 \text { (Foss } \\
\text { Electric A/S, Hillered, } \\
\text { Denmark) }\end{array}$ & $\mathrm{C}$ & $\begin{array}{c}\text { MIR- } \\
\text { spectroscopy }\end{array}$ & $2000-15,000$ & intake & $\begin{array}{c}\text { fat, fatty acid } \\
\text { profile, total } \\
\text { protein, casein, } \\
\text { lactoferrin, } \mathrm{Ca}, \mathrm{P}, \\
\mathrm{Mg}, \mathrm{K}\end{array}$ & $\begin{array}{l}\text { MIR spectroscopy is } \\
\text { suitable for } \\
\text { evaluating genetic } \\
\text { parameters }\end{array}$ & $\begin{array}{c}\mathrm{R}^{2}<0.5 \text { for minerals; } \\
0.2-0.7 \text { for rennet } \\
\text { coagulation time; } 0.7 \\
\text { for fat; } 0.8 \text { for casein; } \\
0.42 \text { for lactoferin }\end{array}$ & {$[61]$} \\
\hline 34 & $\begin{array}{l}\text { handheld spectrometer } \\
4100 \text { EXOSCAN (Agilent } \\
\text { Technologies); tabletop } \\
\text { Nicolet }^{\mathrm{TM}} \text { iS10 FTIR } \\
\text { (Thermo Scientific }^{\mathrm{TM}} \text { ) }\end{array}$ & $\mathrm{C}$ & FT-MIR & $2500-15,384$ & intake & $\begin{array}{l}\text { proteins, fats, } \\
\text { carbohydrates }\end{array}$ & $\begin{array}{l}\text { handheld } \\
\text { FT-MIR-a good } \\
\text { alternative to the } \\
\text { benchtop analyzer for } \\
\text { the analysis of } \\
\text { macrocomponents } \\
\text { in milk }\end{array}$ & $\begin{array}{c}\text { Benchtop: } \mathrm{R}^{2} \text { were } \\
0.96 ; 0.90 ; 0.92 \text { for fats, } \\
\text { proteins, and } \\
\text { carbohydrates, } \\
\text { respectively (PLS } \\
\text { models) } \\
\text { Portable: } \mathrm{R}^{2} \text { were } \\
0.91 ; 0.69 ; 0.86 \text { for fats, } \\
\text { proteins, and } \\
\text { carbohydrates, } \\
\text { respectively } \\
\text { (PLS models) }\end{array}$ & {$[63]$} \\
\hline
\end{tabular}


Table 1. Cont.




Table 1. Cont.

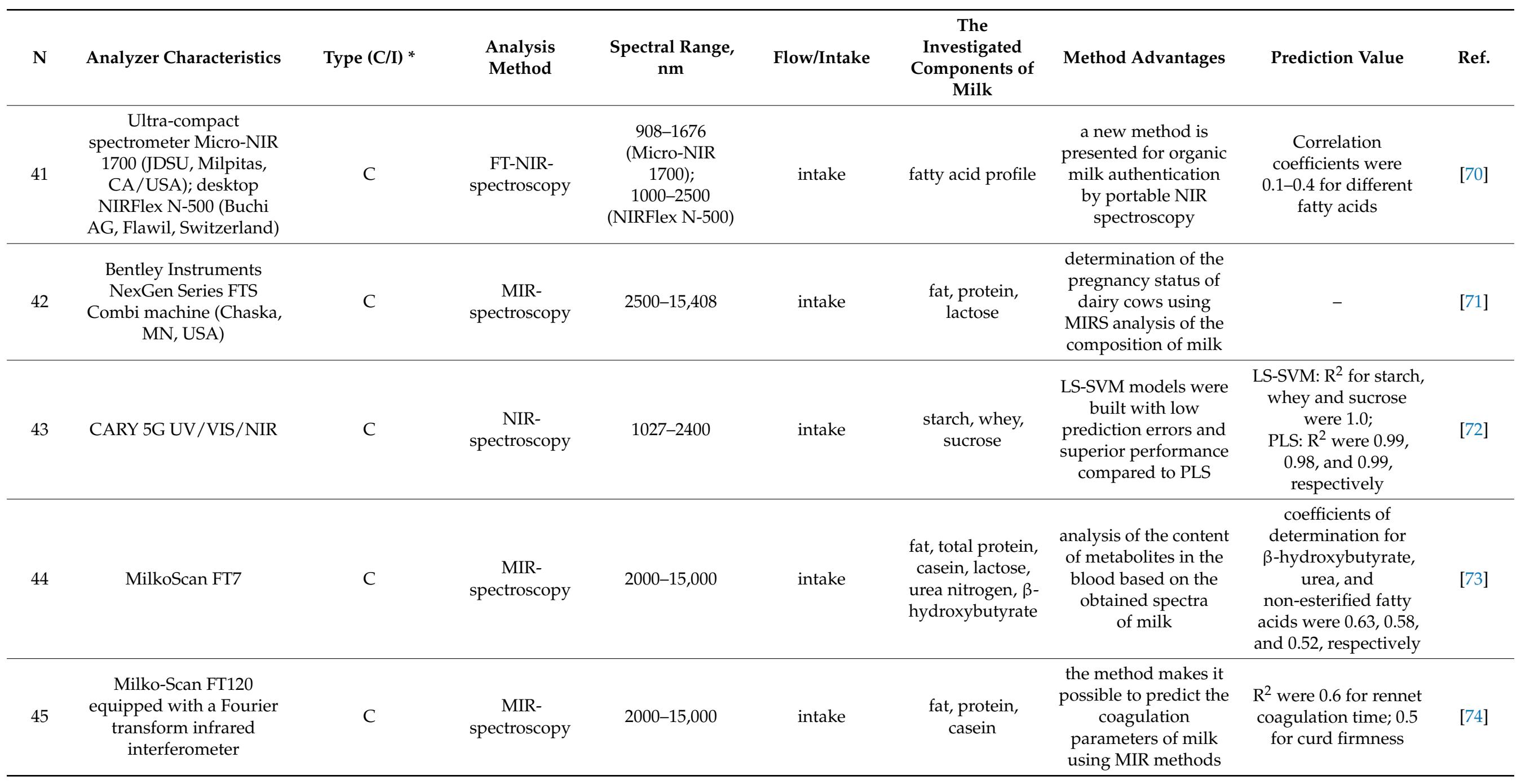


Table 1. Cont.

\begin{tabular}{|c|c|c|c|c|c|c|c|c|c|}
\hline $\mathbf{N}$ & Analyzer Characteristics & Type (C/I) * & $\begin{array}{l}\text { Analysis } \\
\text { Method }\end{array}$ & $\begin{array}{l}\text { Spectral Range, } \\
\mathrm{nm}\end{array}$ & Flow/Intake & $\begin{array}{c}\text { The } \\
\text { Investigated } \\
\text { Components of } \\
\text { Milk }\end{array}$ & Method Advantages & Prediction Value & Ref. \\
\hline 46 & $\begin{array}{c}\text { model } 6500 \\
\text { NIRS scanning } \\
\text { spectrometer (Foss NIR } \\
\text { Systems) }\end{array}$ & $\mathrm{C}$ & $\begin{array}{c}\text { Vis/NIR- } \\
\text { spectroscopy }\end{array}$ & $400-2500$ & intake & fat, protein & $\begin{array}{l}\text { the approach can be } \\
\text { used to authenticate } \\
\text { dairy products }\end{array}$ & - & {$[75]$} \\
\hline 47 & $\begin{array}{c}\text { MilkoScan FT6000 (FOSS } \\
\text { Analytical A/S, Hillerød, } \\
\text { Denmark) }\end{array}$ & $\mathrm{C}$ & $\begin{array}{c}\text { FT-MIR- } \\
\text { spectroscopy }\end{array}$ & $2000-15,000$ & intake & $\begin{array}{l}\text { fat, total protein, } \\
\text { lactose, casein, } \\
\text { acetone (Ac), } \\
\text { acetoacetate } \\
\text { (AcAc), } \beta \text { - } \\
\text { hydroxybutyrate } \\
\text { (BHBA) }\end{array}$ & $\begin{array}{c}\text { the milk analyzer can } \\
\text { be calibrated to detect } \\
\text { subclinical ketosis, } \\
\text { which allows for } \\
\text { additional assessment } \\
\text { of the health of the } \\
\text { herd }\end{array}$ & $\begin{array}{c}\text { Correlation coefficient } \\
\text { for Ac and BHBA } \\
\text { was } 0.8\end{array}$ & {$[76]$} \\
\hline 48 & $\begin{array}{l}\text { the system consisted of } \\
\text { an NIR spectroscopic } \\
\text { instrument, a milk flow } \\
\text { meter, a milk sampler }\end{array}$ & I & $\begin{array}{c}\text { NIR- } \\
\text { spectroscopy }\end{array}$ & $600-1050$ & flow & $\begin{array}{l}\text { fat, protein, } \\
\text { lactose, somatic } \\
\text { cells, urea } \\
\text { nitrogen }\end{array}$ & $\begin{array}{l}\text { NIR spectroscopy can } \\
\text { be used for on-line } \\
\text { monitoring of fat, } \\
\text { protein, lactose, } \\
\text { somatic cells and urea } \\
\text { nitrogen during } \\
\text { milking using a } \\
\text { milking robot with } \\
\text { sufficient accuracy }\end{array}$ & $\begin{array}{l}\mathrm{R}^{2} \text { for fat, protein, } \\
\text { lactose and somatic } \\
\text { cells were } 0.95 ; 0.72 ; \\
0.83 \text {, and } 0.68 \\
\text { respectively }\end{array}$ & {$[77]$} \\
\hline 49 & $\begin{array}{c}\text { Matrix-F FT-NIR, (Bruker, } \\
\text { Germany) }\end{array}$ & C & $\begin{array}{c}\text { FT-NIR- } \\
\text { spectroscopy }\end{array}$ & $800-2500$ & flow & $\begin{array}{l}\text { fat, protein, total } \\
\text { solid content }\end{array}$ & $\begin{array}{c}\text { FT-NIR flow } \\
\text { technology has } \\
\text { demonstrated } \\
\text { accurate, reliable, and } \\
\text { consistent } \\
\text { performance }\end{array}$ & $\begin{array}{c}\text { Correlation coefficient } \\
\text { were } 0.96 \text { for fat; } 0.85 \\
\text { for protein; } 0.96 \text { for } \\
\text { total solid; RPD were } \\
5.1,2.2,1.3 \\
\text { respectively }\end{array}$ & {$[78]$} \\
\hline
\end{tabular}


Table 1. Cont.

\begin{tabular}{|c|c|c|c|c|c|c|c|c|c|}
\hline $\mathbf{N}$ & Analyzer Characteristics & Type $(\mathrm{C} / \mathrm{I})$ * & $\begin{array}{l}\text { Analysis } \\
\text { Method }\end{array}$ & $\begin{array}{c}\text { Spectral Range, } \\
\text { nm }\end{array}$ & Flow/Intake & $\begin{array}{c}\text { The } \\
\text { Investigated } \\
\text { Components of } \\
\text { Milk }\end{array}$ & Method Advantages & Prediction Value & Ref. \\
\hline 50 & $\begin{array}{c}\text { Bruker Equinox } 55 \text { IR } \\
\text { spectrometer using } \\
\text { adeuterated triglycerine } \\
\text { sulfate (DTGS) detector } \\
\text { (Bruker Ltd., Coventry, } \\
\text { UK) }\end{array}$ & $\mathrm{C}$ & $\begin{array}{c}\text { FT-IR- } \\
\text { spectroscopy }\end{array}$ & $2500-20,000$ & intake & $\begin{array}{c}\text { Staphylococcus } \\
\text { aureus, } \\
\text { Lactococcus lactis } \\
\text { ssp.cremoris }\end{array}$ & $\begin{array}{l}\text { FT-IR spectroscopy } \\
\text { made it possible to } \\
\text { fairly well assess the } \\
\text { levels of } S \text {. aureus and } \\
\text { L. lactis in both pure } \\
\text { form and in } \\
\text { co-cultures }\end{array}$ & $\begin{array}{c}\mathrm{R}^{2} \text { varied on average } \\
\text { from } \\
0.78 \text { to } 0.88\end{array}$ & [79] \\
\hline
\end{tabular}

* C—commercial equipment; I—installation, developed in laboratory; $\mathrm{R}^{2}$ —coefficient of determination; RPD—the ratio of performance to deviation. 
Below is a table containing the reviewed literature, which discusses various approaches taken to assess the composition of milk (Table 1). We considered each article according to the following parameters: analyzer characteristics, analysis method, spectral range, ability to work in a stream, determined components, advantages of the method, and a short conclusion for each work. In addition, we indicated the prediction value $\left(R^{2}\right.$ or RPD) for the used model. We also conducted a formal analysis of the data in Table 1 and presented the main patterns in the form of infographics (Figure 2).
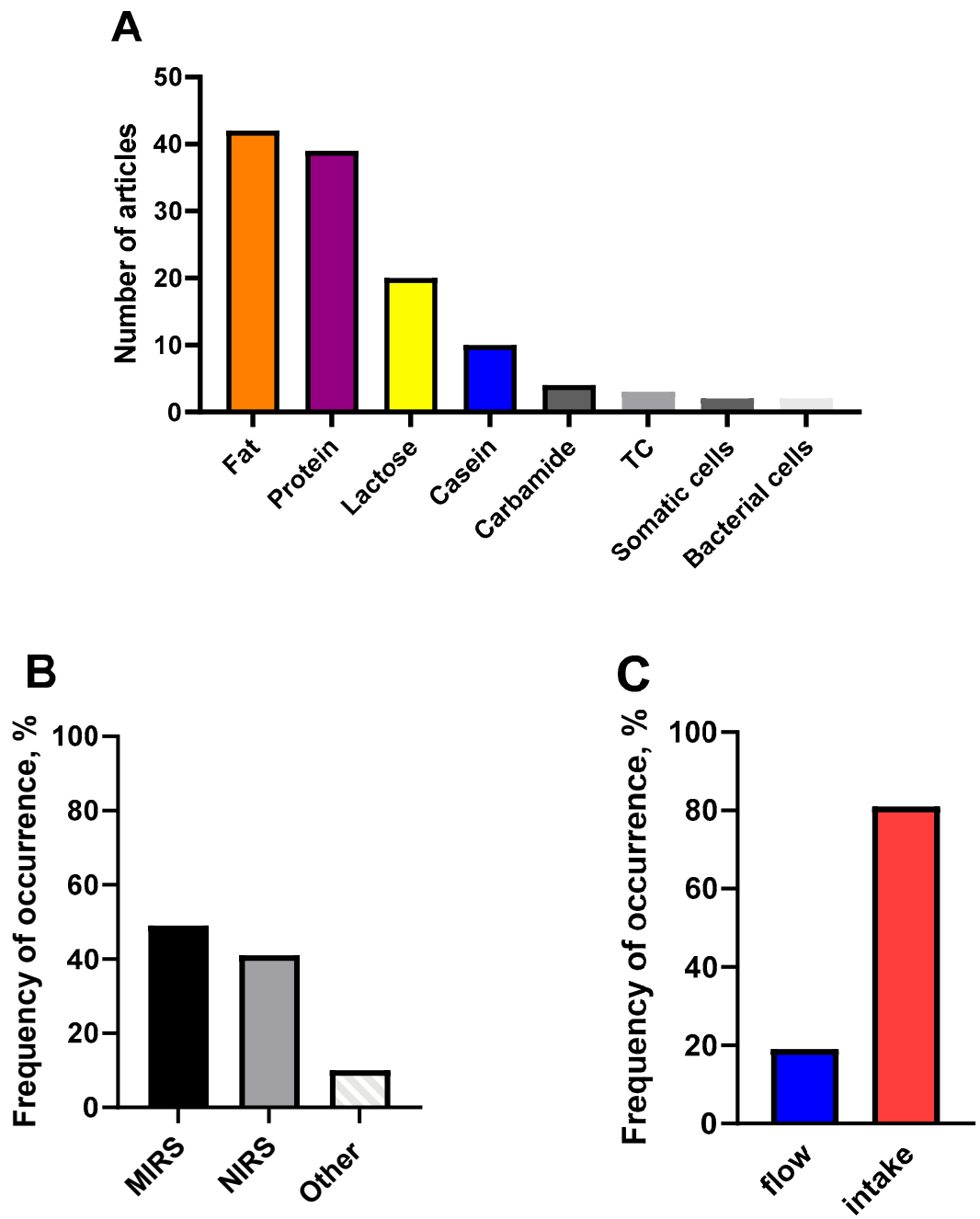

Figure 2. Comparison of the main characteristics of milk analyzers: (A) Distribution of devices according to the analyzed characteristics of milk; TC-Technical characteristic; (B) Distribution of devices according to the used frequency range; (C) Allocation of analyzers by parameter flow/sampling.

The most frequently analyzed components characterizing the quality of the test milk were the concentrations of fat $(\sim 40 \%$ of total), total protein $(\sim 35 \%)$, carbohydrates (lactose) $(\sim 20 \%)$ [64], and specific protein casein ( 10\%) [41] (Figure 2A). There are also studies in which, using spectral methods, urea, and some technical characteristics are detected, for example, liquid flow rate, gas content, etc. A small number of studies using IR spectroscopy considered the possibility of identifying somatic and bacterial cells in milk $[34,60,77]$. The physiological norm for the content of somatic cells in milk is considered to be from 100 to 500 thousand per $\mathrm{mL}$ [80]. An increase in the number of somatic cells (cells of the cylindrical, squamous, and cubic epithelium of the mammary gland, leukocytes, erythrocytes) in milk is a marker of the development of mastitis in an animal [81]. The problem of the early detection of mastitis is quite acute in the modern dairy industry. Cámara- 
Martos et al. [50] reported the detection of E. coli and P. aerogenosa cells by FT-NIRS. Moreover, Nicolaou et al. [79] using FT-IRS, were able to determine the level of S. aureus and Lactococcus lactis ssp. cremoris both in pure form and in cocultures, as well as the cells of other lactococci and enterococci L. lactis, E. durans, E. faecalis, and E. faecium [82]. It has also been reported that it is possible to detect impurities in milk using MIR/NIR spectroscopy, in particular, melamine [67], starch, and sucrose [72].

A significant problem in the analysis of raw milk is the aggregation of fat micelles and protein globules, which prevent accurate diagnosis due to scattering [83]. The presence of water in milk complicates the NIR spectroscopic analysis, and also interferes with the analysis of the presence of micro- and macrobubbles of gases in milk [84].

Milk is a complex colloidal system. The content of the main elements in the composition of cow's milk may vary depending on the individual physiological characteristics of the animal, the season, lactation period, conditions of detention, as well as the breed of the animal. However, on average, cow's milk contains $4.7-4.9 \%$ lactose, which is in a dissolved state; $3.6 \%$ fat in the form of emulsified globules [85]; $3.4 \%$ protein, with a predominance of casein (about $80 \%$ ) in the form of micelles, as well as $\beta$-lactoglobulin and lactoglobulin. Nitrogen in milk $(\mathrm{N})$ is found in two main fractions-true protein and NPN (non-protein nitrogen). True protein makes up 95\%, NPN makes up the remaining 5\% of the total nitrogen in milk. NPN is approximately $30-35 \%$ milk urea, $25 \%$ creatinine/uric acid, $15 \%$ amino acids, and $10-30 \%$ ammonia [86]. The concentration of urea, the main fraction of NPN, in milk is normally about $14.2 \mathrm{mg} / 100 \mathrm{~g}$ of milk $(\sim 5 \mathrm{mM})$ [87]. Milk also contains minerals in the form of salts, also known as ash $(\sim 0.7 \%)$, the main anions of which are chloride, phosphate and citrate, and the cations are sodium, calcium, and magnesium. Milk contains a complex of fat-soluble (A, D, E, K) and water-soluble (B, C) vitamins [86]. Below is a table that lists the main components in the composition of cow's milk in percentage terms (Table 2).

Table 2. Main components of cow milk (adapted from $[85,88,89]$ ).

\begin{tabular}{cc}
\hline Component & $\%$ \\
\hline Water & $85.5-89.5$ \\
\hline Fat & $2.5-6.0$ \\
\hline Protein & $2.9-5.0$ \\
\hline Lactose & $3.6-5.5$ \\
\hline Minerals & $0.6-0.9$ \\
\hline Urea & $<1 \%$ \\
\hline \multicolumn{1}{c}{ Atypical components (impurities) } \\
\hline Starch & $<1 \%$ \\
\hline Sucrose & $<1 \%$ \\
\hline Melamine & $<1 \%$ \\
\hline
\end{tabular}

Milk contains about $88 \%$ water, which leads to the appearance of pronounced bands in the near infrared range of around 960, 1440, 1950, and $2076 \mathrm{~nm}$, which overlap with some bands of milk components [52,75]. In MIRS, the first band of water overlaps with much smaller bands characteristic of the amide I and amide II bands of proteins located in the ranges 5882-6250 $\mathrm{nm}$ and $6369-6451 \mathrm{~nm}$, respectively [90]. One of the most common approaches to increasing the accuracy of milk analysis is to pre-homogenize it. It was shown that the use of homogenization increases the accuracy of predicting the content of fat and protein in milk and does not affect the accuracy of the determined lactose [35]. It was also found that homogenization improves the accuracy of predicting protein content 
in milk using FT-NIR spectroscopy [46]. A number of works have also considered the possibility of determining the profile of fatty acids in milk by the MIRS method [62,91].

A known example is the use of FT-MIR spectroscopy of milk for the early diagnosis of ketosis in cows. Clinical and subclinical ketosis leads to an increase in the concentration of ketone bodies in blood and milk: acetone (Ac), acetoacetate (AcAc), and $\beta$-hydroxybutyrate (BHBA). De Roos et al. [76] reported the successful detection of Ac and BHBA in milk by FT-MIRS using a developed calibration model. The ability to detect ketone bodies in the milk taken is a very important parameter of the analyzer, since it allows the diagnosis of ketosis in individual cows at an early stage without blood sampling.

As seen in Figure 2B, the most popular method for assessing milk quality is midinfrared IR spectroscopy ( $50 \%$ of sources reviewed). About $40 \%$ of all methods and devices work in the near infrared range. Only about $10 \%$ of devices operate in the visible or UV range. Raw milk can be analyzed in both reflection and IR absorption modes. It was previously shown that, for NIRS (1100-2500 nm) analysis of the transmission spectrum of milk, a minimum optical path length $(0.5-1 \mathrm{~mm})$ is required [92,93]. Aernouts et al. [7] compared Vis/NIR reflectance and transmission spectroscopy for the analysis of fat, protein, and lactose, as well as urea in milk. The Vis/NIR reflectance spectra allowed very accurate control of the fat and protein content in raw milk, however did not allow an accurate prediction of the lactose content. In contrast, the transmission spectra of milk samples allowed for accurate predictions of fat, crude protein, and lactose contents. At the same time, none of the approaches made it possible to determine the content of urea in milk [7]. As is known, the level of Milk Urea Nitrogen (MUN) is an important indicator of the protein diet of dairy cows [94,95]. Low MUN content results in reduced milk yield. In this regard, the ability to control the MUN content in milk allows one to adjust the diet of animals on a dairy farm. Only in $\sim 6 \%$ of the sources reviewed by us was the level of urea in milk successfully determined. In particular, Kawasaki et al. [77] developed an NIRS system for real-time milk analysis, which allows for the assessing of the content of not only the three main components of milk (fat, lactose protein), but also urea nitrogen.

It is interesting to note the portable and laboratory (bench-top) IR spectrometers compared in several works. The results obtained from portable devices were in good agreement with the results obtained using bench-top analyzers $[63,70]$. Moreover, several studies have noted the possibility of assessing the technological characteristics of milk, such as rennet coagulation time and curd compaction time, using IR spectroscopy $[57,58,68]$.

As is well known, the method of IR spectroscopy requires the accurate calibration and selection of the optimal algorithm for interpreting the obtained spectra. The most commonly used models are those built using Partial Least Squares regression (PLS) [45,72]. The use of more complex models with preliminary processing of spectral data makes it possible to obtain a more accurate prediction of the content of components in milk. For example, Soyeurt et al. [62] considered the application of six different mathematical methods for preprocessing IR spectra to accurately determine the content of fatty acids in milk samples. Moreover, Bonfatti et al. [57] used various models to predict milk composition using the MIRS method, including Partial Least Squares Regression (PLSR) and Bayesian models. Differences in prediction accuracy between PLSR and Bayesian regression models were zero or insignificant after noise reduction using spectral-mathematical processing. Finally, in a recent report by Frizzarin et al. [56] a statistical machine learning method was used to obtain a more accurate prediction of milk content when analyzed using MIRS compared to PLSR.

Often during laboratory analysis, to preserve the quality of milk, it is frozen, or preservatives are added. Zajac et al. [43] reported that the addition of preservatives (potassium dichromate, azidiol, bronopol) at concentrations of $0.1 \%, 0.5 \%$, and $1 \%$ resulted in significant deviations in MIRS results after $24 \mathrm{~h}$ after adding. The use of flow-through milk analyzers integrated into the milking system makes it possible to solve the problem with the transportation and storage of milk in a laboratory analysis approach [37]. Unfortunately, only a small fraction of currently existing commercial milk analyzers operate in line mode. 
In $\sim 80 \%$ of the literature reviewed by us, laboratory analyzers working with preselected samples were used (Figure 2C).

Thus, the use of IR spectroscopy, including FTIR, in the near and middle spectral ranges is a widely used diagnostic method in the dairy industry. This approach is used mainly to assess the content of three main components in milk that determine its energy value and quality (fat, protein, and lactose). In some cases, spectral methods can identify important markers of animal diseases, and can also be useful for optimizing the production process. The integration of IR transmission spectroscopy into milking systems is hampered by the need to use a thin layer of milk, which leads to a decrease in the speed of its pumping. Reflectance IR spectroscopy solves this problem. However, for a more accurate determination of some components of milk, the development of new methods is required, as well as the improvement of existing calibration models for processing spectral data for existing methods.

\section{Application of IR Spectroscopy to Analyze the Quality of Feed}

The composition of vegetable feed that forms the diet of agricultural animals is an important factor in the productivity of dairy farming. We have analyzed modern literary sources devoted to the study of the use of IR spectroscopy for the diagnosis of feed for farm animals (see Table 3). Near infrared reflection spectroscopy (NIRS) is predominantly used for feed analysis ( $90 \%$ of the sources we reviewed), and only $~ 10 \%$ of the studies used MIRS analysis (Figure 3A). The most important and often analyzed components of feed for farm animals, which determine their energy value and digestibility, are the content of crude protein (CP), fats, neutral-detergent fiber (NDF), acid-detergent fiber $(\mathrm{ADF})$, water soluble carbohydrates (WSC), as well as total nitrogen (N) (see Figure 3B). Acid Detergent Fiber (ADF), a cellulose and lignin, is an important parameter of feed quality that negatively correlates with feed digestibility [96]. The NDF parameter is the total mass of plant cell walls, consisting of the ADF fraction and hemicellulose. NDF values are also an important characteristic of feed, as they reflect the amount of plant feed that an animal can consume. Typically, as the proportion of NDF increases, dry matter intake tends to decrease. These components have been successfully identified using NIRS for alfalfa (Medicago sativa) [97], Italian ryegrass (Lolium multiflorum) [98], willow (Salix spp.) [99,100], corn (Zea mays) [21,101], sorghum (Sorghum bicolor) [102], and other plants used as feed for farm animals. NIR is most sensitive to vibrations of covalent bonds of hydrogen atoms with atoms of other chemical elements. As is known, organic molecules of plant biopolymers are rich in covalent bonds $\mathrm{C}-\mathrm{H}, \mathrm{O}-\mathrm{H}$, and $\mathrm{N}-\mathrm{H}$ [103]. However, the absorption of NIR by water strongly overlaps most of the NIR spectrum of biomolecules [104]. In this regard, for a more accurate analysis of a plant feed sample using NIRS in laboratory conditions, it is usually pre-dried and milled [105,106]. It is important to note the possibility of detecting toxins in the feed composition using NIRS. The possibility of detecting hydrogen cyanide in fodder sorghum (Sorghum bicolor) using an NIRS analyzer was shown by Fox et al. [102].

The IVDMD method (in vitro dry matter digestibility) and the IVOMD method (in vitro organic matter digestibility), also well known as the Tilley and Terry method [107], are commonly used to assess the nutritional value of feed for ruminants. IVOMD and IVDMD are determined by subtracting organic matter $(\mathrm{OM})$ and dry matter $(\mathrm{DM})$ residues from the original values before fermentation in rumen fluid, respectively. Samadi et al. [108] considered the possibility of predicting the nutritional value of feed from residues from the food industry using the analysis of NIR spectra. Moreover, Zgouz et al. [109] reported the possibility of determining IVOMD using eight different commercial portable spectrometers. 
Table 3. Main characteristics of optical methods and devices used to assess the quality of feed.

\begin{tabular}{|c|c|c|c|c|c|c|c|c|c|}
\hline $\mathbf{N}$ & $\begin{array}{c}\text { Analyzer } \\
\text { Characteristics }\end{array}$ & Type (C/I) * & $\begin{array}{l}\text { Analysis } \\
\text { Method }\end{array}$ & $\begin{array}{c}\text { Spectral Range, } \\
\mathrm{nm}\end{array}$ & Object & $\begin{array}{l}\text { The Investigated } \\
\text { Parameters of Feed }\end{array}$ & Method Advantages & Prediction Value & Ref. \\
\hline 1 & $\begin{array}{c}\text { Thermo Fisher } \\
\text { Scientific Nicolet } 5700 \\
\text { equipped with Smart } \\
\text { iTR TM Attenuated } \\
\text { Total Reflectance } \\
\text { sampling device }\end{array}$ & $\mathrm{C}$ & $\begin{array}{l}\text { ATR-FT-MIR } \\
\text { spectroscopy }\end{array}$ & $2500-14,815$ & $\begin{array}{c}\text { ryegrass, } \\
\text { white clover, } \\
\text { chicory, } \\
\text { plantain }\end{array}$ & DM, hemicellulose & $\begin{array}{l}\text { portable method for } \\
\text { analysis of feed } \\
\text { composition }\end{array}$ & $\begin{array}{l}\mathrm{R}^{2} \text { were } 0.92 \text { and } 0.86 \\
\text { for hemicellulose and } \\
\text { neutral detergent } \\
\text { fiber, respectively }\end{array}$ & [23] \\
\hline 2 & $\begin{array}{c}\text { spectrometer with an } \\
\text { array of micromirrors } \\
\text { and a single-element } \\
\text { detector }\end{array}$ & I & $\begin{array}{c}\text { NIR- } \\
\text { spectroscopy }\end{array}$ & $800-2500$ & lucerne & $\mathrm{CP}, \mathrm{NDF}, \mathrm{ADF}$ & $\begin{array}{l}\text { a high-performance } \\
\text { portable NIR } \\
\text { spectrometer with an } \\
\text { embedded } \\
\text { chemometric model } \\
\text { has been developed to } \\
\text { extract the necessary } \\
\text { information about the } \\
\text { quality of feed }\end{array}$ & $\begin{array}{c}\mathrm{R}^{2} \text { were } 0.516,0.742, \\
0.704, \text { for } \mathrm{CP}, \mathrm{ADF}, \\
\text { NDF, respectively }\end{array}$ & [97] \\
\hline 3 & - & I & $\begin{array}{c}\text { NIR- } \\
\text { spectroscopy }\end{array}$ & $1000-2500$ & $\begin{array}{c}\text { fermented } \\
\text { sago residues }\end{array}$ & $\begin{array}{l}\text { NDF, ADF, in vitro } \\
\text { dry matter } \\
\text { digestibility } \\
\text { (IVDMD), in vitro } \\
\text { organic matter } \\
\text { digestibility } \\
\text { (IVOMD) }\end{array}$ & $\begin{array}{l}\text { excellent results for } \\
\text { IVDMD, IVOMD, and } \\
\text { NDF predictions have } \\
\text { been achieved }\end{array}$ & $\begin{array}{l}\text { RPD were } 2.78 \text { for } \\
\text { IVDMD; } 2.35 \text { for } \\
\text { IVOMD; } 2.31 \text { for NDF; } \\
3.00 \text { for ADF }\end{array}$ & [110] \\
\hline 4 & $\begin{array}{c}\text { Bruker MPA (Bruker, } \\
\text { Bremen, Germany) }\end{array}$ & $\mathrm{C}$ & $\begin{array}{c}\text { FT-NIR- } \\
\text { spectroscopy }\end{array}$ & $800-2500$ & $\begin{array}{l}\text { Italian } \\
\text { ryegrass } \\
\text { (Lolium } \\
\text { multiflorum) }\end{array}$ & $\mathrm{CP}, \mathrm{ADF}, \mathrm{NDF}, \mathrm{WSC}$ & $\begin{array}{l}\text { four optimal NIRS } \\
\text { models have been } \\
\text { developed to predict } \\
\text { CP, NDF, ADF, and } \\
\text { WSC content in } \\
\text { Italian ryegrass } \\
\text { samples }\end{array}$ & $\begin{array}{l}\text { RPD for CP } 8.58 \text {; for } \\
\text { NDF 4.25; for ADF } \\
\text { 3.64; for WSC } 3.10\end{array}$ & [98] \\
\hline
\end{tabular}


Table 3. Cont

\begin{tabular}{|c|c|c|c|c|c|c|c|c|c|}
\hline $\mathbf{N}$ & $\begin{array}{c}\text { Analyzer } \\
\text { Characteristics }\end{array}$ & Type $(\mathrm{C} / \mathrm{I})$ * & $\begin{array}{l}\text { Analysis } \\
\text { Method }\end{array}$ & $\begin{array}{c}\text { Spectral Range, } \\
\text { nm }\end{array}$ & Object & $\begin{array}{l}\text { The Investigated } \\
\text { Parameters of Feed }\end{array}$ & Method Advantages & Prediction Value & Ref. \\
\hline 5 & $\begin{array}{l}\text { FOSS NIRSystems } 5000 \\
\text { (FOSS NIRSystems, } \\
\text { Silver Spring, MD); } \\
\text { PoliSPEC NIR PL1 and } \\
\text { PL2 (ITPhoton-ics, } \\
\text { Breganze, Italy) }\end{array}$ & $\mathrm{C}$ & $\begin{array}{c}\text { NIR- } \\
\text { spectroscopy }\end{array}$ & $\begin{array}{c}1100-2500 \\
\text { (FOSS } \\
\text { NIRSystems } \\
5000) ; \\
902-1680 \\
\text { (PoliSPEC NIR) } \\
\end{array}$ & corn silage & $\begin{array}{l}\text { DM, ash, CP, NDF, } \\
\text { ADF, starch, total } \\
\text { sugar (TS) }\end{array}$ & $\begin{array}{l}\text { poliSPECNIR PL2 } \\
\text { gave more accurate } \\
\text { predictions of feed } \\
\text { composition than PL1 }\end{array}$ & $\begin{array}{c}0.72>\mathrm{R}^{2}<0.97 \text { for } \\
\mathrm{DM}, \text { ash and NDF; } \\
0.78>\mathrm{R}^{2}<0.82 \text { for } \\
\mathrm{CP} \text { and ADF }\end{array}$ & [101] \\
\hline 6 & $\begin{array}{c}\text { eight kinds of handheld } \\
\text { spectrometers: DLP } \\
\text { NIRscan Nano EVM, } \\
\text { F750, LabSpec 4, } \\
\text { MicroNIR1700, } \\
\text { MicroNIR2200, } \\
\text { NI-RONE 2.2, Scio, } \\
\text { TellSpec }\end{array}$ & $\mathrm{C}$ & $\begin{array}{c}\text { NIR- } \\
\text { spectroscopy }\end{array}$ & $\begin{array}{c}\text { 350-2500 } \\
\text { (LabSpec 4); } \\
\text { 901-1701 } \\
\text { (NIRscan Nano } \\
\text { EVM); 450-1140 } \\
\text { (F750); 908-1676 } \\
\text { (MicroNIR1700); } \\
\text { 1158-2169 } \\
\text { (MicroNIR2200); } \\
\text { 1750-2150 } \\
\text { (NIRONE 2.2); } \\
\text { 740-1070 (Scio); } \\
\text { 900-1700 } \\
\text { (TellSpec) }\end{array}$ & $\begin{array}{l}\text { Saccharum } \\
\text { officinarum }\end{array}$ & $\begin{array}{l}\text { TS, CP, ADF, } \\
\text { IVOMD }\end{array}$ & $\begin{array}{l}\text { successful prediction } \\
\text { of the composition of } \\
\text { dried sugar cane by } \\
\text { eight commercial } \\
\text { mini-spectrometers } \\
\text { with varying accuracy }\end{array}$ & $\begin{array}{c}\mathrm{R}^{2} \text { for TS: } \\
\text { DLP NIRscan 0.86; } \\
\text { F750 0.72; } \\
\text { LabSpec } 4 \text { 0.97; } \\
\text { MicroNIR1700 0.94; } \\
\text { MicroNIR2200 0.97; } \\
\text { NIRONE 2.2 0.79; } \\
\text { Scio 0.68; TellSpec } \\
\text { 0.69; } \\
\text { R² for CP: DLP } \\
\text { NIRscan 0.65; } \\
\text { F750 087; LabSpec } 4 \\
\text { 0.92; } \\
\text { MicroNIR1700 0.91; } \\
\text { MicroNIR2200 0.89; } \\
\text { NIRONE 2.2 090; Scio } \\
\text { 0.87; TellSpec 0.73 }\end{array}$ & [109] \\
\hline 7 & $\begin{array}{c}\text { NIRSystems } 6500 \\
\text { scanning } \\
\text { monochromator (FOSS, } \\
\text { Silver Spring, MD, } \\
\text { USA) with a } \\
\text { transportmodule }\end{array}$ & $\mathrm{C}$ & $\begin{array}{c}\text { NIR- } \\
\text { spectroscopy }\end{array}$ & $400-2500$ & $\begin{array}{l}\text { Meadow } \\
\text { grasses }\end{array}$ & $\begin{array}{l}\text { total N; nitrogen in } \\
\text { the substance } \\
\text { precipitated by } \\
\text { trichloroacetic acid; } \\
\text { insoluble nitrogen } \\
\text { in borate-phosphate } \\
\text { buffer; insoluble } \\
\text { nitrogen in neutral } \\
\text { detergents; acid } \\
\text { detergent insoluble } \\
\text { nitrogen (ADIN) }\end{array}$ & $\begin{array}{l}\text { accurately predicted } \\
\text { the content of total } \\
\text { nitrogen, nitrogen in } \\
\text { the substance } \\
\text { precipitated by } \\
\text { trichloroacetic acid, } \\
\text { and nitrogen } \\
\text { insoluble in neutral } \\
\text { detergents }\end{array}$ & $\begin{array}{c}\mathrm{R}^{2} \text { were } 0.97 \text { for total } \\
\mathrm{N} \text {; } 0.91 \text { for nitrogen in } \\
\text { the substance } \\
\text { precipitated by } \\
\text { trichloroacetic acid; } \\
0.69 \text { for insoluble } \\
\text { nitrogen in } \\
\text { borate-phosphate } \\
\text { buffer; } 0.95 \text { for } \\
\text { insoluble nitrogen in } \\
\text { neutral detergents; } \\
0.74 \text { for ADIN }\end{array}$ & [10] \\
\hline
\end{tabular}


Table 3. Cont

\begin{tabular}{|c|c|c|c|c|c|c|c|c|c|}
\hline $\mathbf{N}$ & $\begin{array}{c}\text { Analyzer } \\
\text { Characteristics }\end{array}$ & Type (C/I) * & $\begin{array}{l}\text { Analysis } \\
\text { Method }\end{array}$ & $\begin{array}{c}\text { Spectral Range, } \\
\text { nm }\end{array}$ & Object & $\begin{array}{l}\text { The Investigated } \\
\text { Parameters of Feed }\end{array}$ & Method Advantages & Prediction Value & Ref. \\
\hline 8 & $\begin{array}{c}\text { FieldSpec Pro } \\
\text { (Analytical Spectral } \\
\text { Devices, Incorporated) }\end{array}$ & $\mathrm{C}$ & $\begin{array}{c}\text { NIR- } \\
\text { spectroscopy }\end{array}$ & $350-1050$ & Salix spp. & $\begin{array}{l}\mathrm{CP}, \mathrm{NDF}, \mathrm{ADF} \text {, acid } \\
\text { detergent lignin, } \\
\text { acid insoluble ash, } \\
\text { tannins, digestible } \\
\text { protein (DP), } \\
\text { digestible dry } \\
\text { matter (DDM) }\end{array}$ & $\begin{array}{c}\text { feed quality } \\
\text { indicators such as DP } \\
\text { and DDM can be } \\
\text { successfully } \\
\text { quantified using } \\
\text { hyperspectral remote } \\
\text { sensing data }\end{array}$ & $\begin{array}{l}\mathrm{R}^{2} \text { were } 0.81 \text { for } \mathrm{DP} ; \\
0.73 \text { for } \mathrm{DDM} ;\end{array}$ & [99] \\
\hline 9 & $\begin{array}{l}\text { Unity Spectrastar 2500X } \\
\text { rotating top window } \\
\text { system (Unity Scientific, } \\
\text { Milford, MA, } \\
\text { USA) }\end{array}$ & $\mathrm{C}$ & $\begin{array}{c}\text { NIR- } \\
\text { spectroscopy }\end{array}$ & $680-2500$ & $\begin{array}{l}\text { herbs, } \\
\text { legumes }\end{array}$ & $\begin{array}{c}\text { total } \mathrm{N}, \mathrm{CP}, \mathrm{NDF}, \\
\mathrm{ADF}\end{array}$ & $\begin{array}{l}\text { broad calibrations } \\
\text { predict the } \\
\text { performance of } \\
\text { annual grasses, } \\
\text { annual legumes, and } \\
\text { forbs more accurately } \\
\text { than perennial } \\
\text { grasses or legumes }\end{array}$ & $\begin{array}{c}\text { RPD were } 5.3 \text { for CP; } \\
4.3 \text { for NDF; } 3.7 \text { for } \\
\text { ADF; } 2.2 \text { for organic } \\
\text { matter }\end{array}$ & {$[111]$} \\
\hline 10 & $\begin{array}{c}\text { benchtop-type (FOSS) } \\
\text { and two handheld NIR } \\
\text { devices (microPHAZIR } \\
\text { and DLP NIRscan Nano } \\
\text { EVM) }\end{array}$ & $\mathrm{C}$ & $\begin{array}{c}\text { NIR- } \\
\text { spectroscopy }\end{array}$ & $\begin{array}{c}1100-2498 \\
\text { (FOSS); } \\
\text { 1600-2400 } \\
\text { (microPHAZIR); } \\
\text { 900-1700 (DLP } \\
\text { NIRscan) }\end{array}$ & $\begin{array}{l}\text { Panicum } \\
\text { virgatum } \mathrm{L} ., \\
\text { Cynodon } \\
\text { dactylon (L.) }\end{array}$ & $\begin{array}{l}\text { CP, ADF, NDF, } \\
\text { IVTD }\end{array}$ & $\begin{array}{l}\text { the ability to predict } \\
\text { component content } \\
\text { for both handheld } \\
\text { devices was similar to } \\
\text { that of a desktop } \\
\text { device }\end{array}$ & $\begin{array}{l}\mathrm{R}^{2} \text { were } 0.81-0.87 \text { for } \\
\mathrm{NDF} ; 0.96-0.99 \text { for } \mathrm{CP} ; \\
0.84 \text { for ADF; } 0.9-0.97 \\
\text { for IVTD }\end{array}$ & {$[112]$} \\
\hline 11 & $\begin{array}{l}\text { NIRSystem } 6500 \text { (Foss } \\
\text { NIRSystems, Inc., Silver } \\
\text { Spring, MD, USA) }\end{array}$ & $\mathrm{C}$ & $\begin{array}{c}\text { NIR- } \\
\text { spectroscopy }\end{array}$ & $400-2498$ & $\begin{array}{l}\text { Sorghum } \\
\text { bicolor }(\mathrm{L} .) \\
\text { Moench } \times \\
\text { Sorghum } \\
\text { sudanense } \\
\text { Stapf. cv. } \\
\text { Superdan }\end{array}$ & $\begin{array}{l}\text { hydrogen cyanide } \\
\text { (HCN) }\end{array}$ & $\begin{array}{l}\text { possibility of using } \\
\text { NIR to predict HCN } \\
\text { content in feed } \\
\text { sorghum }\end{array}$ & $\begin{array}{c}\text { PLS model: } \mathrm{R}^{2}= \\
0.838 ; \\
\text { multiple linear } \\
\text { regression (MLR) } \\
\text { approach: } \mathrm{R}^{2}=0.847\end{array}$ & {$[102]$} \\
\hline 12 & $\begin{array}{c}\text { SVC HR 1024-i, (Spectra } \\
\text { Vista Corporation, } \\
\text { Poughkeepsie, NY, } \\
\text { USA) }\end{array}$ & $\mathrm{C}$ & $\begin{array}{c}\text { vis-NIR- } \\
\text { spectroscopy }\end{array}$ & $350-2500$ & $\begin{array}{c}\text { herbal crops of } \\
\text { mountain } \\
\text { pastures }\end{array}$ & $\begin{array}{l}\text { ash, fat, protein, } \\
\text { fiber }\end{array}$ & $\begin{array}{l}\text { fast, economical, and } \\
\text { high-performance } \\
\text { method for analyzing } \\
\text { feed quality }\end{array}$ & $\begin{array}{l}\mathrm{R}^{2} \text { were } 0.83 \text { for ash; } \\
0.86 \text { for fat; } 0.42 \text { for } \\
\text { fiber; } 0.93 \text { for protein }\end{array}$ & [11] \\
\hline
\end{tabular}


Table 3. Cont

\begin{tabular}{|c|c|c|c|c|c|c|c|c|c|}
\hline $\mathbf{N}$ & $\begin{array}{c}\text { Analyzer } \\
\text { Characteristics }\end{array}$ & Type $(\mathrm{C} / \mathrm{I}) *$ & $\begin{array}{l}\text { Analysis } \\
\text { Method }\end{array}$ & $\begin{array}{c}\text { Spectral Range, } \\
\text { nm }\end{array}$ & Object & $\begin{array}{l}\text { The Investigated } \\
\text { Parameters of Feed }\end{array}$ & Method Advantages & Prediction Value & Ref. \\
\hline 13 & $\begin{array}{c}\text { SpectraStar } 2600 \text { XT-R, } \\
\text { (Unity Scientific, } \\
\text { Columbia, MD, USA) }\end{array}$ & $\mathrm{C}$ & $\begin{array}{c}\text { NIR- } \\
\text { spectroscopy }\end{array}$ & $680-2600$ & $\begin{array}{c}\text { Cyamopsis } \\
\text { tetragonoloba, } \\
\text { Phaseolus } \\
\text { acutifolius, } \\
\text { Cajanus cajan, } \\
\text { Glycine max, } \\
\text { Vigna } \\
\text { aconitifolia }\end{array}$ & $\begin{array}{l}\text { CP, NDF, ADF, } \\
\text { IVTD }\end{array}$ & $\begin{array}{l}\text { NIRS methods can be } \\
\text { effective in providing } \\
\text { fast and accurate } \\
\text { predictions of most } \\
\text { feed quality } \\
\text { characteristics for } \\
\text { various warm-season } \\
\text { legumes; machine } \\
\text { learning algorithms } \\
\text { such as SVM can also } \\
\text { develop robust } \\
\text { models with relatively } \\
\text { few samples }\end{array}$ & $\begin{array}{c}\text { PLS model: } \mathrm{R}^{2} \text { were } \\
0.94-0.98 \text { for all } \\
\text { forage quality } \\
\text { parameters }\end{array}$ & [113] \\
\hline 14 & $\begin{array}{l}\text { Foss NIRSystem } 6500 \\
\text { (Foss North America, } \\
\text { MN); AuroraNir } \\
\text { (Grainit srl, Italy); } \\
\text { NIR-S-G1 (Innospectra, } \\
\text { Taiwan); SCiO } \\
\text { (Consumer Physics, } \\
\text { Hod Hasharon, Israel) }\end{array}$ & $\mathrm{C}$ & $\begin{array}{c}\text { NIR- } \\
\text { spectroscopy }\end{array}$ & $\begin{array}{c}\text { 1100-2498 } \\
\text { (FOSS); } \\
950-1650 \\
\text { (AuroraNir, } \\
\text { NIR-S-G1); } \\
\text { 740-1070 (SCiO) }\end{array}$ & $\begin{array}{c}\text { Medicago sativa } \\
\text { L. }\end{array}$ & $\begin{array}{l}\text { NDF, ADF, ADL, } \\
\text { IVTD }\end{array}$ & $\begin{array}{l}\text { portable analyzers } \\
\text { AuroraNir and } \\
\text { NIR-S-G1 are an } \\
\text { alternative to } \\
\text { expensive benchtop } \\
\text { laboratory equipment, } \\
\text { while providing } \\
\text { reasonably accurate } \\
\text { predictions }\end{array}$ & $\begin{array}{l}\text { AuroraNir: } \mathrm{R}^{2}=0.97 \\
\text { for CP; } 0.95 \text { for NDF; } \\
0.96 \text { for ADF; } 0.93 \text { for } \\
\text { ADL; } 0.90 \text { for IVTD; } \\
\text { NIR-S-G1: } \mathrm{R}^{2}=0.94 \\
\text { for CP; } 0.91 \text { for NDF; } \\
0.93 \text { for ADF; } 0.86 \text { for } \\
\text { ADL; } 0.87 \text { for IVTD }\end{array}$ & [114] \\
\hline 15 & $\begin{array}{l}\text { Vector22/N, (Bruker, } \\
\text { Ettlingen, Germany) }\end{array}$ & $\mathrm{C}$ & $\begin{array}{c}\text { NIR- } \\
\text { spectroscopy }\end{array}$ & $833-2500$ & $\begin{array}{l}\text { Zea Mays ssp. } \\
\text { L. }\end{array}$ & $\begin{array}{l}\text { \% in vitro } \\
\text { digestibility, } \\
\text { NDF, ADF, CP, } \\
\text { Crude Fat }\end{array}$ & $\begin{array}{l}\text { the optimal timing of } \\
\text { harvesting corn at the } \\
\text { peak of the total } \\
\text { assimilable energy } \\
\text { was proposed }\end{array}$ & - & [21] \\
\hline 16 & $\begin{array}{l}\text { Lambda FTIR-7600 c } \\
\text { ATR (Tianjin Gangdong } \\
\text { Sci. \& Tech. } \\
\text { Development Co. Ltd., } \\
\text { Nankai, China) }\end{array}$ & $\mathrm{C}$ & $\begin{array}{c}\text { FT-MIR- } \\
\text { spectroscopy }\end{array}$ & $2500-12,500$ & $\begin{array}{l}\text { ceHo Medicago } \\
\text { sativa L. }\end{array}$ & $\begin{array}{c}\text { spectral profiles and } \\
\text { chemical properties } \\
\text { of protein amides I } \\
\text { and II }\end{array}$ & $\begin{array}{c}\text { non-invasive } \\
\text { molecular } \\
\text { spectroscopy } \\
\text { methods are able to } \\
\text { detect the features of } \\
\text { the internal protein } \\
\text { structure of feed }\end{array}$ & - & [106] \\
\hline
\end{tabular}


Table 3. Cont

\begin{tabular}{|c|c|c|c|c|c|c|c|c|c|}
\hline $\mathbf{N}$ & $\begin{array}{c}\text { Analyzer } \\
\text { Characteristics }\end{array}$ & Type (C/I) * & $\begin{array}{l}\text { Analysis } \\
\text { Method }\end{array}$ & $\begin{array}{c}\text { Spectral Range, } \\
\mathrm{nm}\end{array}$ & Object & $\begin{array}{l}\text { The Investigated } \\
\text { Parameters of Feed }\end{array}$ & Method Advantages & Prediction Value & Ref. \\
\hline 17 & $\begin{array}{l}\text { NIRS DS2500-FOSS } \\
\text { Analytrical } \\
\text { A/S-Denmark) }\end{array}$ & $\mathrm{C}$ & $\begin{array}{l}\text { NIR- } \\
\text { spectroscopy }\end{array}$ & - & $\begin{array}{c}\text { Vicia faba, Zea } \\
\text { mayz var. ICA } \\
\text { V-305, } \\
\text { Raphanus } \\
\text { sativus L., Beta } \\
\text { vulgaris, Avena } \\
\text { sativa var. } \\
\text { Cayuse, } \\
\text { Phalaris sp., } \\
\text { Medicago sativa } \\
\text { L. var. moapa, } \\
\text { Medicago sativa } \\
\text { L. }\end{array}$ & $\begin{array}{l}\mathrm{DM}, \mathrm{CP}, \mathrm{NDF}, \mathrm{ADF}, \\
\text { lignin, } \\
\text { hemicellulose, dry } \\
\text { matter digestibility } \\
\text { and net energy of } \\
\text { lactation (ENL) }\end{array}$ & $\begin{array}{l}\text { comparison of } \\
\text { nutritional } \\
\text { characteristics of } \\
\text { different types of } \\
\text { forage plants using } \\
\text { NIRS }\end{array}$ & - & [115] \\
\hline 18 & $\begin{array}{c}\text { UAV with a camera } \\
\text { with a spectral sensor } \\
\text { Cubert Hyperspectral } \\
\text { Fire-fleye S185 SE } \\
\text { (Cubert GmbH, (Ulm, } \\
\text { Germany) }\end{array}$ & $\mathrm{C}$ & $\begin{array}{c}\text { vis-NIR- } \\
\text { spectroscopy }\end{array}$ & $482-950$ & $\begin{array}{l}\text { hay meadows, } \\
\text { Nardus stricta, } \\
\text { Lupinus } \\
\text { polyphyllus }\end{array}$ & $\mathrm{CP}, \mathrm{ADF}$ & $\begin{array}{l}\text { the resulting models } \\
\text { can accurately } \\
\text { estimate the content } \\
\text { of crude protein and } \\
\text { acid-detergent fiber } \\
\text { regardless of the type } \\
\text { of pasture; the } \\
\text { accuracy of the } \\
\text { models is in the same } \\
\text { range as the accuracy } \\
\text { obtained using field } \\
\text { spectroscopy }\end{array}$ & $\begin{array}{l}\mathrm{R}^{2} \text { were } 0.33-0.4 \text { for } \\
\mathrm{CP} ; 0.23-0.33 \text { for ADF }\end{array}$ & [116] \\
\hline 19 & $\begin{array}{l}\text { Foss NIRSystems } \\
\text { model } 6500 \text { (Foss } \\
\text { NIRSystems, Silver } \\
\text { Spring, MD, USA) }\end{array}$ & $\mathrm{C}$ & $\begin{array}{l}\text { Vis-NIR- } \\
\text { spectroscopy }\end{array}$ & $400-2500$ & silage & $\begin{array}{l}\mathrm{N}, \mathrm{NDF}, \mathrm{ADF} \text {, dry } \\
\text { matter digestibility } \\
\text { pepsin cellulase } \\
\text { (PCDMD) }\end{array}$ & $\begin{array}{l}\text { the developed } \\
\text { calibration equations } \\
\text { are sufficiently } \\
\text { reliable for successful } \\
\text { prediction of the } \\
\text { considered } \\
\text { parameters for } \\
\text { permanent grass } \\
\text { hayfields }\end{array}$ & $\begin{array}{l}\text { RPD were } 7.95,4.28 \\
4.23,5.23 \text { for N, NDF, } \\
\text { ADF, PCDMD, } \\
\text { respectively }\end{array}$ & [117] \\
\hline
\end{tabular}


Table 3. Cont

\begin{tabular}{|c|c|c|c|c|c|c|c|c|c|}
\hline $\mathbf{N}$ & $\begin{array}{c}\text { Analyzer } \\
\text { Characteristics }\end{array}$ & Type (C/I) * & $\begin{array}{l}\text { Analysis } \\
\text { Method }\end{array}$ & $\begin{array}{c}\text { Spectral Range, } \\
\text { nm }\end{array}$ & Object & $\begin{array}{l}\text { The Investigated } \\
\text { Parameters of Feed }\end{array}$ & Method Advantages & Prediction Value & Ref. \\
\hline 20 & $\begin{array}{c}\text { XDS-NIRS rapid } \\
\text { content analyzer (FOSS } \\
\text { Analytical, } \\
\text { Slangerupgade, } \\
\text { Denmark) }\end{array}$ & $\mathrm{C}$ & $\begin{array}{c}\text { NIR- } \\
\text { spectroscopy }\end{array}$ & $400-2498$ & soybean & $\begin{array}{l}\mathrm{CP} \text {, crude fat, } \\
\mathrm{NDF}, \mathrm{ADF}\end{array}$ & $\begin{array}{l}\text { the developed NIR } \\
\text { calibration equations } \\
\text { are useful for } \\
\text { predicting the quality } \\
\text { of soybeans according } \\
\text { to the considered } \\
\text { quality parameters }\end{array}$ & $\begin{array}{c}\mathrm{R}^{2} \text { were } 0.92,0.94 \\
0.84,0.78 \text { for } \mathrm{CP}, \mathrm{CF}, \\
\mathrm{NDF}, \mathrm{ADF}, \\
\text { respectively }\end{array}$ & [22] \\
\hline 22 & $\begin{array}{c}\text { Foss NIRS model } 6500 \\
\text { (FOSS Analytical, } \\
\text { Slangerupgade, } \\
\text { Denmark) }\end{array}$ & $\mathrm{C}$ & $\begin{array}{c}\text { NIR- } \\
\text { spectroscopy }\end{array}$ & $400-2500$ & $\begin{array}{c}\text { Salix } \\
\text { caroliniana }\end{array}$ & $\begin{array}{l}\mathrm{CP}, \mathrm{ADF}, \mathrm{NDF}, \\
\text { lignin, } \\
\text { gross energy (GE), } \\
\text { condensed tannin } \\
\text { (CT) }\end{array}$ & $\begin{array}{l}\text { accurate prediction of } \\
\text { the content of the } \\
\text { considered } \\
\text { components in the } \\
\text { leaves and stems of } \\
\text { willow collected in } \\
\text { different seasons and } \\
\text { years }\end{array}$ & $\begin{array}{c}\mathrm{R}^{2}>0.75 \text { for } \mathrm{CP}, \mathrm{ADF} \\
\mathrm{NDF}, \text { and } \mathrm{GE} ; \mathrm{R}^{2}= \\
0.72 \text { for } \mathrm{CT}\end{array}$ & [100] \\
\hline 23 & $\begin{array}{l}\text { NIRS DS2500 (Foss UK } \\
\text { Ltd., Warrington, UK) }\end{array}$ & $\mathrm{C}$ & $\begin{array}{c}\text { NIR- } \\
\text { spectroscopy }\end{array}$ & $1100-2500$ & $\begin{array}{l}\text { hay, grass, } \\
\text { silage }\end{array}$ & $\begin{array}{l}\text { mineral content }(\mathrm{Ca} \text {, } \\
\mathrm{P}, \mathrm{K}, \mathrm{S}, \mathrm{Mg}, \mathrm{Na})\end{array}$ & $\begin{array}{l}\text { the importance of } \\
\text { preliminary } \\
\text { preparation of the } \\
\text { sample under study is } \\
\text { shown; drying and } \\
\text { grinding of samples } \\
\text { increased the } \\
\text { accuracy of NIRS } \\
\text { analysis }\end{array}$ & $\begin{array}{c}\text { Hay: } \mathrm{R}^{2} \text { were } 0.31 ; \\
0.30 ; 0.48 ; 0.41 ; 0.35 \\
0.31 \text { for } \mathrm{Ca}, \mathrm{P}, \mathrm{Mg}, \mathrm{K} \\
\mathrm{S}, \mathrm{Na} \text {, respectively }\end{array}$ & [105] \\
\hline
\end{tabular}


Table 3. Cont.

\begin{tabular}{|c|c|c|c|c|c|c|c|c|c|}
\hline $\mathbf{N}$ & $\begin{array}{c}\text { Analyzer } \\
\text { Characteristics }\end{array}$ & Type (C/I) * & $\begin{array}{l}\text { Analysis } \\
\text { Method }\end{array}$ & $\begin{array}{c}\text { Spectral Range, } \\
\mathrm{nm}\end{array}$ & Object & $\begin{array}{l}\text { The Investigated } \\
\text { Parameters of Feed }\end{array}$ & Method Advantages & Prediction Value & Ref. \\
\hline 24 & $\begin{array}{c}\text { Thermo Nicolet Antaris } \\
\text { II TM }\end{array}$ & $\mathrm{C}$ & $\begin{array}{c}\text { NIR- } \\
\text { spectroscopy }\end{array}$ & $1000-2500$ & $\begin{array}{l}\text { sago leftovers, } \\
\text { coconut flour, } \\
\text { soy and } \\
\text { ketchup } \\
\text { by-products, } \\
\text { coffee pulp, } \\
\text { cocoa pods, } \\
\text { sago tree, ear } \\
\text { of corn }\end{array}$ & $\begin{array}{l}\text { IVOMD, IVDMD, } \\
\text { NDF, ADF }\end{array}$ & $\begin{array}{c}\text { fast and reliable } \\
\text { prediction and } \\
\text { determination of } \\
\text { several nutritional } \\
\text { parameters of animal } \\
\text { feeds simultaneously }\end{array}$ & $\begin{array}{c}\mathrm{R}^{2} \text { were } 0.75,0.83, \\
0.59,0.61 \text { for } \mathrm{NDF}, \\
\mathrm{ADF}, \mathrm{IVOMD} \\
\text { IVDMD, respectively }\end{array}$ & [108] \\
\hline 25 & $\begin{array}{l}\text { MPA, Opus Bruker, } \\
\text { (Germany) }\end{array}$ & $\mathrm{C}$ & $\begin{array}{c}\text { FT-NIR- } \\
\text { spectroscopy }\end{array}$ & $800-2778$ & $\begin{array}{c}\text { grassland } \\
\text { plant samples }\end{array}$ & $\mathrm{CP}, \mathrm{NDF}$ & $\begin{array}{l}\text { significant correlation } \\
\text { between NIRS } \\
\text { calibration models } \\
\text { and reference } \\
\text { methods for } \\
\text { quantifying pasture } \\
\text { quality parameters } \\
\text { with greater accuracy } \\
\text { in dry samples }\end{array}$ & $\begin{array}{c}\text { dry samples: } \\
\mathrm{R}^{2}=0.936 \text { and } \\
\mathrm{RPD}=4.01 \text { for } \mathrm{CP} \\
\mathrm{R}^{2}=0.914 \text { and } \\
\mathrm{RPD}=3.48 \text { for } \mathrm{NDF} \\
\text { fresh samples: } \\
\mathrm{R}^{2}=0.702 \text { and } \\
\mathrm{RPD}=1.88 \text { for } \mathrm{CP} \\
\mathrm{R}^{2}=0.720 \text { and } \\
\mathrm{RPD}=2.38 \text { for } \mathrm{NDF}\end{array}$ & [119] \\
\hline
\end{tabular}

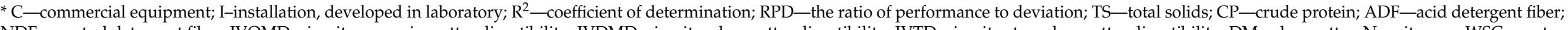

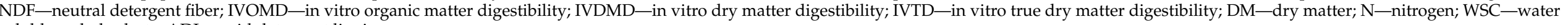
soluble carbohydrate; ADL-acid detergent lignin. 

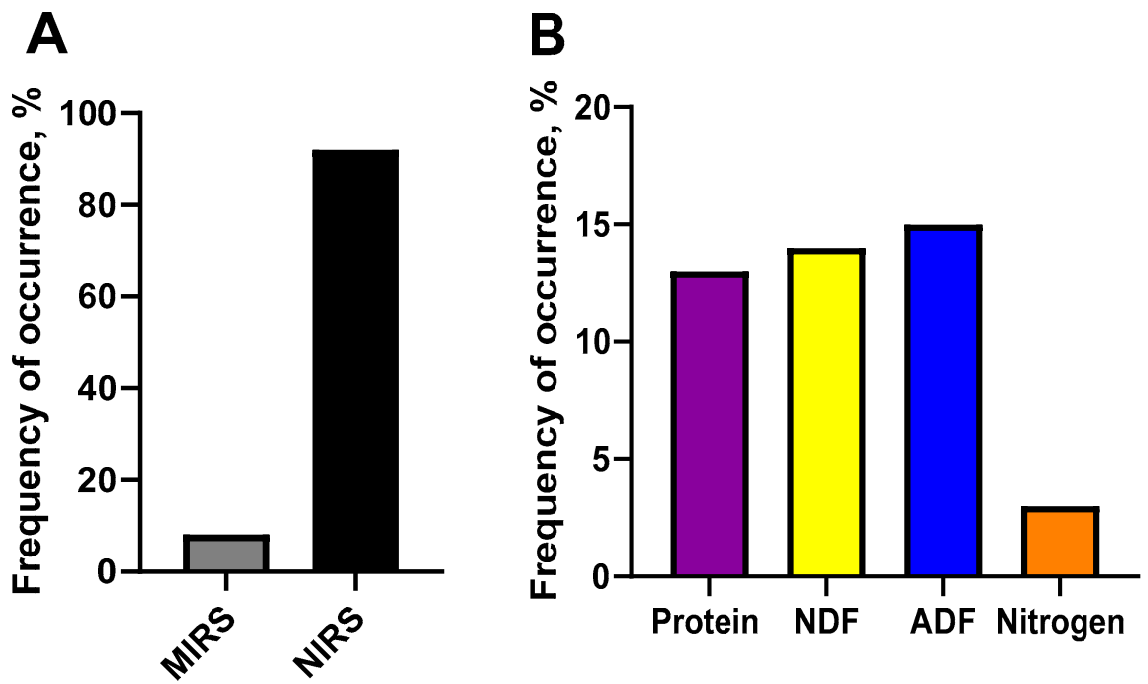

Figure 3. Comparison of the main characteristics of feed analyzers: (A) Distribution of devices according to the used frequency range. (B) Distribution of devices according to the analyzed characteristics.

A high carbohydrate content with a very low fat and protein content reduces the quality of the feed. Thus, there is a need for the regular monitoring of pastures in order to control the quality of forage crops. Despite the need to calibrate most analyzers using wet chemistry methods, as well as to develop an accurate model for interpreting spectral data, the use of NIRS is the most optimal and cost-effective [11]. Currently, there are a large number of commercial solutions for FTIR spectral analysis, both for laboratory feed diagnostics and for field use in the form of portable analyzers [97], including those with the ability to register a large area using unmanned aerial vehicles (UAVs) $[99,116,120]$. In this regard, there are several approaches for measurement: point mapping, linear mapping, terrain mapping using a matrix in the focal plane, and hyperspectral imaging. Point mapping is an analysis at a specific point of an object, followed by movement to another point. Linear display is a collection of spectra in one line and then moving along another parallel line. Terrain mapping using a focal plane array (FPA) allows all spectra to be recorded without moving the sample in a short period of time. Hyperspectral imaging allows one to obtain images at wavelengths in the near infrared range. For this measurement, a large amount of data is collected in a hyperspectral cube, where three axes include two spatial and one spectral axis. This visualization can be created in one of four ways: two-point spectral scanning in a spatial grid pattern, Fourier transform visualization, line-by-line spatial scanning, and wavelength tuning using filters. In this cube, the sample is divided into small areas of surface or volume (called pixels), each representing a full spectrum. A cube is displayed as a three-dimensional matrix or data cube that spans two spatial dimensions ( $\mathrm{x}$ and $\mathrm{y}$ ). The third dimension $(\mathrm{z})$ corresponds to the individual wavelength/wavenumber $[20,121]$. Nowadays, terrain mapping using hyperspectral imaging is increasingly used. In particular, Wijesingha et al. [116] reported successful assessment of $\mathrm{CP}$ and $\mathrm{ADF}$ content in vegetation cover regardless of pasture type. At the same time, the accuracy of the applied calibration models did not differ from those used in "field" spectroscopy. Thus, remote sensing is a promising tool for assessing feed quality in the field compared to traditional methods, which usually do not provide as detailed information.

The use of portable analyzers can be convenient for assessing the quality of feed in the field [23,95]. Berzaghi et al. [114] in a recent report, compared handheld IR spectrometers to benchtop analyzers. The high accuracy of the results obtained using portable analyzers was noted. Moreover, Acosta et al. [112] did not find a difference in the determination of the component composition of forage hay for millet Panicum virgatum L. and Bermuda grass 
Cynodon dactylon (L.) when using two portable analyzers in comparison with a stationary spectrometer.

To date, several methods are known for constructing calibration models for processing NIRS data for assessing feed quality. The most common and widely used methods are partial least squares regression (PLS), principal component regression (PCR) $[23,117,122]$, and multiple linear regression (MLR) [102]. In addition, relatively new approaches are the use of machine learning algorithms such as support vector machine (SVM) and Gaussian processes (GP) [123,124]. Specifically, Baath et al. [113] compared SVM and GP machine learning methods with PCR for predicting feed composition for NIRS analysis. The SVM model made it possible to accurately determine the composition of crops Cyamopsis tetragonoloba and Glycine max. In turn, the SVM and PLS models showed the best results for beans (Phaseolus acutifolius) and pigeon peas (Cajanus cajan). A combination of NIRS calibration methods can serve as an approach to optimize spectral data processing, eliminating the need for classic feed analysis methods.

Thus, NIRS is an effective analytical method for the rapid and non-invasive analysis of the chemical composition of various types of plant feed. This method is very sensitive, environmentally friendly, and does not require expensive reagents, which makes its use economically beneficial for farms. Currently, NIRS can be used not only to determine the "classic set" of feed components such as moisture, dry matter, crude protein, crude fiber, NDF, and ADF, but also to identify minerals, trace elements, enzymes, and toxins. Hy-perspective probing of pastures makes it possible to assess the species composition of the vegetation cover and to map the area to optimize fertilization. Finally, NIRS probing can be useful in determining the optimal harvest time for forage crops to achieve the maximum energy value of the forage harvested.

\section{Future Directions/Prospects for the Development of Optical Technologies for Quality Control on the Farm}

The analysis of literature has shown that IR spectroscopy is a convenient method of analysis for agricultural applications. A compact IR spectrometer is a promising tool in production; however, for its accurate and fast operation, it is necessary to develop and improve chemometric algorithms for processing spectral data. The use of the analyzers in real time also does not seem possible without modern data processing algorithms and highperformance capacities. Another direction for the development of optical analysis systems in production is the synchronization of automated processes. In particular, a promising approach is the synchronization of data on significant changes in the composition of milk obtained from an individual animal and data on the composition of its diet. Moreover, the synchronization of the milking process and the analysis of milk can be useful for the detection of markers of cattle pathologies in milk, and, as a result, the rapid cessation of milk production for a given animal. It is important to note the prospects of using portable infrared analyzers, mainly NIRS, in the field, in particular, for assessing the state of pastures and the growth of forage crops. The use of such analyzers in conjunction with unmanned aerial vehicles with subsequent mapping of the terrain will optimize farm costs for irrigation and fertilization. Thus, the improvement of automated optical analysis systems, mainly IR spectrometry, is an economically demanded solution for both small farms and large industrial complexes. Creation of "smart farms", which implies the automation and synchronization of the diagnostic processes, feeding, and milking of the animal on the farm. This approach significantly improves the quality of life of animals on the farm, which is a key factor in obtaining high quality products and, as a result, the high profitability of this agricultural production.

\section{Conclusions}

Today, optical methods are accurate, fast, and non-destructive analytical instruments that can be considered as a good alternative to traditional chemical analysis. Numerous studies accumulated over the past decades demonstrate the possibility of using spectral methods to analyze a wide range of components of agricultural products, including those of 
both plant and animal origin. Currently, there is a large number of analyzers that allow one to accurately determine the composition of the object under study, both during sampling and in flow mode.

One of the main promising directions in the development of spectral analysis systems is the integration of IR analyzers into automated quality control systems. This approach can be a useful solution for the timely detection of pathologies of animals, improving the quality of products and optimizing the production process as a whole. An important element in optimizing the production process on the farm is to control the quality of feed for farm animals. Fast and automated analysis of feed used in production reduces the economic costs of keeping animals. Such automation on the farm is of great interest, since it allows for the synchronizing of the process of feeding the animal and obtaining high quality dairy products with a known composition. The increase in productivity and the reduction in the cost of computing power, observed recently, allow for the processing of large amounts of data at a relatively high speed. Thus, the creation of new and the improvement of existing chemometric mathematical models make it possible to achieve the high accuracy and speed of the processing of IR spectroscopy data.

Author Contributions: Conceptualization, D.Y.P., S.V.G. and A.V.Z.; formal analysis, V.N.L. and Y.P.L.; data curation, A.R.K. and E.A.N.; writing—original draft preparation, D.E.B.; writing—review and editing, S.V.G. and A.V.Z.; visualization, D.N.I.; supervision, A.V.Z. All authors have read and agreed to the published version of the manuscript.

Funding: This work was supported by a grant of the Ministry of Science and Higher Education of the Russian Federation for large scientific projects in priority areas of scientific and technological development (grant number 075-15-2020-774).

Institutional Review Board Statement: Not applicable.

Informed Consent Statement: Not applicable.

Data Availability Statement: Not applicable.

Conflicts of Interest: The authors declare no conflict of interest.

\section{References}

1. Górska-Warsewicz, H.; Rejman, K.; Laskowski, W.; Czeczotko, M. Milk and Dairy Products and Their Nutritional Contribution to the Average Polish Diet. Nutrients 2019, 11, 1771. [CrossRef]

2. Visioli, F.; Strata, A. Milk, Dairy Products, and Their Functional Effects in Humans: A Narrative Review of Recent Evidence. Adv. Nutr. 2014, 5, 131-143. [CrossRef] [PubMed]

3. Gerrior, S.; Putnam, J.; Bente, L. Milk and milk products: Their importance in the American diet. Food Rev. Natl. Food Rev. 1998, 21, 29-37.

4. Kubicová, L.; Habánová, M. Development of milk consumption and marketing analysis of its demand. Potravin. Slovak J. Food Sci. 2012, 6, 66-72.

5. Bórawski, P.; Kalinowska, B.; Mickiewicz, B.; Parzonko, A.; Klepacki, B.; Dunn, J.W. Changes in the Milk Market in the United States on the Background of the European Union and the World. Eur. Res. Stud. J. 2021, 24, 1010-1033. [CrossRef]

6. Shahbandeh, M. Global Cow Milk Production 2015 to 2020. Available online: https://www.statista.com/topics/4649/dairyindustry/ (accessed on 1 October 2021).

7. Aernouts, B.; Polshin, E.; Lammertyn, J.; Saeys, W. Visible and near-infrared spectroscopic analysis of raw milk for cow health monitoring: Reflectance or transmittance? J. Dairy Sci. 2011, 94, 5315-5329. [CrossRef]

8. Luiz, L.d.C.; Bell, M.J.V.; Rocha, R.A.d.; Leal, N.L.; Anjos, V.d.C.d. Detection of Veterinary Antimicrobial Residues in Milk through Near-Infrared Absorption Spectroscopy. J. Spectrosc. 2018, 2018, 5152832. [CrossRef]

9. Shenk, J.S.; Workman, J.J., Jr.; Westerhaus, M.O. Application of NIR spectroscopy to agricultural products. In Handbook of Near-Infrared Analysis; CRC Press: Boca Raton, FL, USA, 2007; pp. 365-404.

10. Valdés, C.; Andrés, S.; Giraldez, F.J.; García, R.; Calleja, A. Potential use of visible and near infrared reflectance spectroscopy for the estimation of nitrogen fractions in forages harvested from permanent meadows. J. Sci. Food Agric. 2006, 86, 308-314. [CrossRef]

11. Berauer, B.J.; Wilfahrt, P.A.; Reu, B.; Schuchardt, M.A.; Garcia-Franco, N.; Zistl-Schlingmann, M.; Dannenmann, M.; Kiese, R.; Kühnel, A.; Jentsch, A. Predicting forage quality of species-rich pasture grasslands using vis-NIRS to reveal effects of management intensity and climate change. Agric. Ecosyst. Environ. 2020, 296, 106929. [CrossRef] 
12. Nocita, M.; Stevens, A.; van Wesemael, B.; Aitkenhead, M.; Bachmann, M.; Barthès, B.; Ben Dor, E.; Brown, D.J.; Clairotte, M.; Csorba, A.; et al. Soil Spectroscopy: An Alternative to Wet Chemistry for Soil Monitoring. In Advances in Agronomy; Sparks, D.L., Ed.; Academic Press: Cambridge, MA, USA, 2015; Volume 132, pp. 139-159, Chapter Four.

13. Robson, A.; Phinn, S.; Wright, G.; Fox, G. Combining near infrared spectroscopy and infrared aerial imagery for assessment of peanut crop maturity and aflatoxin risk. In Proceedings of the 4th International Crop Science Congress, Brisbane, QLD, Australia, 26 September-1 October 2004.

14. Yang, D.; Ying, Y. Applications of Raman spectroscopy in agricultural products and food analysis: A review. Appl. Spectrosc. Rev. 2011, 46, 539-560. [CrossRef]

15. Dong, Z.; Men, Y.; Liu, Z.; Li, J.; Ji, J. Application of chlorophyll fluorescence imaging technique in analysis and detection of chilling injury of tomato seedlings. Comput. Electron. Agric. 2020, 168, 105109. [CrossRef]

16. Coates, J. Interpretation of infrared spectra, a practical approach. In Encyclopedia of Analytical Chemistry; John Wiley \& Sons Ltd.: Chichester, UK, 2000.

17. Manley, M. Near-infrared spectroscopy and hyperspectral imaging: Non-destructive analysis of biological materials. Chem. Soc. Rev. 2014, 43, 8200-8214. [CrossRef]

18. Beć, K.B.; Grabska, J.; Huck, C.W. Near-Infrared Spectroscopy in Bio-Applications. Molecules 2020, 25, 2948. [CrossRef]

19. Evangelista, C.; Basiricò, L.; Bernabucci, U. An Overview on the Use of Near Infrared Spectroscopy (NIRS) on Farms for the Management of Dairy Cows. Agriculture 2021, 11, 296. [CrossRef]

20. Türker-Kaya, S.; Huck, C.W. A Review of Mid-Infrared and Near-Infrared Imaging: Principles, Concepts and Applications in Plant Tissue Analysis. Molecules 2017, 22, 168. [CrossRef]

21. Fu, F.-L.; Guo, C.-J.; Tang, Q.-L.; Jian, L.; Li, W.-C. Growth dynamics and optimal harvesting stage of two forage maize varieties. Agric. Sci. China 2011, 10, 220-227. [CrossRef]

22. Asekova, S.; Han, S.-I.; Choi, H.-J.; Park, S.-J.; Shin, D.-H.; Kwon, C.-H.; Shannon, J.G.; LEE, J.D. Determination of forage quality by near-infrared reflectance spectroscopy in soybean. Turk. J. Agric. For. 2016, 40, 45-52. [CrossRef]

23. Cleland, J.D.; Johnson, E.; Morel, P.C.; Kenyon, P.R.; Waterland, M.R. Mid-infrared reflectance spectroscopy as a tool for forage feed composition prediction. Anim. Feed. Sci. Technol. 2018, 241, 102-111. [CrossRef]

24. Griffiths, P. Fourier transform infrared spectrometry. Science 1983, 222, 297-302. [CrossRef] [PubMed]

25. Legner, N.; Meinen, C.; Rauber, R. Root Differentiation of Agricultural Plant Cultivars and Proveniences Using FTIR Spectroscopy. Front. Plant Sci. 2018, 9, 748. [CrossRef] [PubMed]

26. Li, X.C.; Zhao, J.M.; Wang, C.C.; Liu, L.H. Improved transmission method for measuring the optical extinction coefficient of micro/nano particle suspensions. Appl. Opt. 2016, 55, 8171-8179. [CrossRef]

27. Soulat, J.; Andueza, D.; Graulet, B.; Girard, C.L.; Labonne, C.; Ait-Kaddour, A.; Martin, B.; Ferlay, A. Comparison of the potential abilities of three spectroscopy methods: Near-infrared, mid-infrared, and molecular fluorescence, to predict carotenoid, vitamin and fatty acid contents in cow milk. Foods 2020, 9, 592. [CrossRef]

28. Kirsanov, V.V.; Shkirin, A.V.; Pavkin, D.Y.; Ignatenko, D.N.; Danielyan, G.L.; Khakimov, A.R.; Bunkin, N.F. Laser Fluorescence and Extinction Methods for Measuring the Flow and Composition of Milk in a Milking Machine. Photonics 2021, 8, 390. [CrossRef]

29. Shkirin, A.V.; Ignatenko, D.N.; Chirikov, S.N.; Bunkin, N.F.; Astashev, M.E.; Gudkov, S.V. Analysis of Fat and Protein Content in Milk Using Laser Polarimetric Scatterometry. Agriculture 2021, 11, 1028. [CrossRef]

30. Kirichenko, M.N.; Chaikov, L.L.; Shkirin, A.V.; Krasovskii, V.I.; Bulychev, N.A.; Kazaryan, M.A.; Krivokhizha, S.V.; Milovich, F.O.; Chirikov, S.N. General Features of Size Distributions and Internal Structure of Particles in Aqueous Nanosuspensions. Phys. Wave Phenom. 2020, 28, 140-144. [CrossRef]

31. Melfsen, A.; Hartung, E.; Haeussermann, A. Accuracy of milk composition analysis with near infrared spectroscopy in diffuse reflection mode. Biosyst. Eng. 2012, 112, 210-217. [CrossRef]

32. Yang, B.; Huang, X.; Yan, X.; Zhu, X.; Guo, W. A cost-effective on-site milk analyzer based on multispectral sensor. Comput. Electron. Agric. 2020, 179, 105823. [CrossRef]

33. Saeedi, S.; Chamaani, S. Non-contact Time Domain Ultra Wide Band Milk Spectroscopy. IEEE Sens. J. 2021, $21,13849-13857$. [CrossRef]

34. Teng, Z.; Yang, G.; Wang, L.; Fu, T.; Lian, H.; Sun, Y.; Han, L.; Zhang, L.; Gao, T. Effects of the circadian rhythm on milk composition in dairy cows: Does day milk differ from night milk? J. Dairy Sci. 2021, 104, 8301-8313. [CrossRef] [PubMed]

35. Di Marzo, L.; Barbano, D.M. Effect of homogenizer performance on accuracy and repeatability of mid-infrared predicted values for major milk components. J. Dairy Sci. 2016, 99, 9471-9482. [CrossRef] [PubMed]

36. de la Roza-Delgado, B.; Garrido-Varo, A.; Soldado, A.; Arrojo, A.G.; Valdés, M.C.; Maroto, F.; Pérez-Marín, D. Matching portable NIRS instruments for in situ monitoring indicators of milk composition. Food Control 2017, 76, 74-81. [CrossRef]

37. Diaz-Olivares, J.A.; Adriaens, I.; Stevens, E.; Saeys, W.; Aernouts, B. Online milk composition analysis with an on-farm nearinfrared sensor. Comput. Electron. Agric. 2020, 178, 105734. [CrossRef]

38. Aernouts, B.; Adriaens, I.; Diaz-Olivares, J.; Saeys, W.; Mäntysaari, P.; Kokkonen, T.; Mehtiö, T.; Kajava, S.; Lidauer, P.; Lidauer, M.H. Mid-infrared spectroscopic analysis of raw milk to predict the blood nonesterified fatty acid concentrations in dairy cows. J. Dairy Sci. 2020, 103, 6422-6438. [CrossRef] [PubMed]

39. Muñiz, R.; Cuevas-Valdés, M.; de la Roza-Delgado, B. Milk quality control requirement evaluation using a handheld near infrared reflectance spectrophotometer and a bespoke mobile application. J. Food Compos. Anal. 2020, 86, 103388. [CrossRef] 
40. Soufleri, A.; Banos, G.; Panousis, N.; Fletouris, D.; Arsenos, G.; Valergakis, G. Genetic parameters of colostrum traits in Holstein dairy cows. J. Dairy Sci. 2019, 102, 11225-11232. [CrossRef]

41. Cheruiyot, E.K.; Bett, R.C.; Amimo, J.O.; Mujibi, F.D. Milk composition for admixed dairy cattle in Tanzania. Front. Genet. 2018, 9 , 142. [CrossRef]

42. Di Marzo, L.; Cree, P.; Barbano, D.M. Prediction of fat globule particle size in homogenized milk using Fourier transform mid-infrared spectra. J. Dairy Sci. 2016, 99, 8549-8560. [CrossRef]

43. Zajác, P.; Zubrická, S.; Čapla, J.; Zeleňáková, L.; Židek, R.; Čurlej, J. Effect of preservatives on milk composition determination. Int. Dairy J. 2016, 61, 239-244. [CrossRef]

44. Bogomolov, A.; Belikova, V.; Galyanin, V.; Melenteva, A.; Meyer, H. Reference-free spectroscopic determination of fat and protein in milk in the visible and near infrared region below $1000 \mathrm{~nm}$ using spatially resolved diffuse reflectance fiber probe. Talanta 2017, 167, 563-572. [CrossRef]

45. Melenteva, A.; Galyanin, V.; Savenkova, E.; Bogomolov, A. Building global models for fat and total protein content in raw milk based on historical spectroscopic data in the visible and short-wave near infrared range. Food Chem. 2016, 203, 190-198. [CrossRef]

46. Wang, Y.; Guo, W.; Zhu, X.; Liu, Q. Effect of homogenisation on detection of milk protein content based on NIR diffuse reflectance spectroscopy. Int. J. Food Sci. Technol. 2019, 54, 387-395. [CrossRef]

47. Rico, D.; Marshall, E.; Choi, J.; Kaylegian, K.; Dechow, C.; Harvatine, K. Within-milking variation in milk composition and fatty acid profile of Holstein dairy cows. J. Dairy Sci. 2014, 97, 4259-4268. [CrossRef]

48. Galyanin, V.; Melenteva, A.; Bogomolov, A. Selecting optimal wavelength intervals for an optical sensor: A case study of milk fat and total protein analysis in the region 400-1100 nm. Sens. Actuators B Chem. 2015, 218, 97-104. [CrossRef]

49. Bogomolov, A.; Melenteva, A.; Dahm, D.J. Fat globule size effect on visible and shortwave near infrared spectra of milk. J. Near Infrared Spectrosc. 2013, 21, 435-440. [CrossRef]

50. Cámara-Martos, F.; Lopes, J.A.; Moreno-Rojas, R.; Pérez-Rodríguez, F. Detection and quantification of Escherichia coli and Pseudomonas aeruginosa in cow milk by near-infrared spectroscopy. Int. J. Dairy Technol. 2015, 68, 357-365. [CrossRef]

51. Adams, M.C.; Barbano, D.M. A novel statistical approach to detect differences in fat and protein test values among mid-infrared spectrophotometers. J. Dairy Sci. 2015, 98, 4174-4181. [CrossRef]

52. Mohamed, H.; Nagy, P.; Agbaba, J.; Kamal-Eldin, A. Use of near and mid infra-red spectroscopy for analysis of protein, fat, lactose and total solids in raw cow and camel milk. Food Chem. 2021, 334, 127436. [CrossRef] [PubMed]

53. Dimitrova, T.; Eftimov, T.; Kabadzhov, V.; Panayotov, P.; Boyanova, P. Scattering and fluorescence spectra of cow milk. Bulg. Chem. Commun. 2014, 46, 39-43.

54. Iweka, P.; Kawamura, S.; Mitani, T.; Koseki, S. Non-destructive online real-time milk quality determination in a milking robot using near-infrared spectroscopic sensing system. Arid. Zone J. Eng. Technol. Environ. 2018, 14, 121-128.

55. Kaniyamattam, K.; De Vries, A. Agreement between milk fat, protein, and lactose observations collected from the Dairy Herd Improvement Association (DHIA) and a real-time milk analyzer. J. Dairy Sci. 2014, 97, 2896-2908. [CrossRef]

56. Frizzarin, M.; Gormley, I.; Berry, D.; Murphy, T.; Casa, A.; Lynch, A.; McParland, S. Predicting cow milk quality traits from routinely available milk spectra using statistical machine learning methods. J. Dairy Sci. 2021, 104, 7438-7447. [CrossRef]

57. Bonfatti, V.; Tiezzi, F.; Miglior, F.; Carnier, P. Comparison of Bayesian regression models and partial least squares regression for the development of infrared prediction equations. J. Dairy Sci. 2017, 100, 7306-7319. [CrossRef]

58. Bonfatti, V.; Degano, L.; Menegoz, A.; Carnier, P. Mid-infrared spectroscopy prediction of fine milk composition and technological properties in Italian Simmental. J. Dairy Sci. 2016, 99, 8216-8221. [CrossRef] [PubMed]

59. Bonfatti, V.; Di Martino, G.; Carnier, P. Effectiveness of mid-infrared spectroscopy for the prediction of detailed protein composition and contents of protein genetic variants of individual milk of Simmental cows. J. Dairy Sci. 2011, 94, 5776-5785. [CrossRef] [PubMed]

60. Cipolat-Gotet, C.; Cecchinato, A.; De Marchi, M.; Penasa, M.; Bittante, G. Comparison between mechanical and near-infrared methods for assessing coagulation properties of bovine milk. J. Dairy Sci. 2012, 95, 6806-6819. [CrossRef]

61. Bonfatti, V.; Vicario, D.; Lugo, A.; Carnier, P. Genetic parameters of measures and population-wide infrared predictions of 92 traits describing the fine composition and technological properties of milk in Italian Simmental cattle. J. Dairy Sci. 2017, 100, 5526-5540. [CrossRef] [PubMed]

62. Soyeurt, H.; Dehareng, F.; Gengler, N.; McParland, S.; Wall, E.; Berry, D.; Coffey, M.; Dardenne, P. Mid-infrared prediction of bovine milk fatty acids across multiple breeds, production systems, and countries. J. Dairy Sci. 2011, 94, 1657-1667. [CrossRef]

63. Gorla, G.; Mestres, M.; Boqué, R.; Riu, J.; Spanu, D.; Giussani, B. ATR-MIR spectroscopy to predict commercial milk major components: A comparison between a handheld and a benchtop instrument. Chemom. Intell. Lab. Syst. 2020, $200,103995$. [CrossRef]

64. Lei, Y.; Zhou, Q.; Zhang, Y.-L.; Chen, J.-B.; Sun, S.-Q.; Noda, I. Analysis of crystallized lactose in milk powder by Fouriertransform infrared spectroscopy combined with two-dimensional correlation infrared spectroscopy. J. Mol. Struct. 2010, 974, 88-93. [CrossRef]

65. Salleh, N.A.; Selamat, J.; Meng, G.Y.; Abas, F.; Jambari, N.N.; Khatib, A. Fourier transform infrared spectroscopy and multivariate analysis of milk from different goat breeds. Int. J. Food Prop. 2019, 22, 1673-1683. [CrossRef] 
66. De Marchi, M.; Fagan, C.; O’Donnell, C.A.; Cecchinato, A.; Dal Zotto, R.; Cassandro, M.; Penasa, M.; Bittante, G. Prediction of coagulation properties. titrable acidity. and $\mathrm{pH}$ of bovine milk using mid-infrared spectroscopy. J. Dairy Sci. 2009, 92, 423-432. [CrossRef]

67. Balabin, R.M.; Smirnov, S.V. Melamine detection by mid-and near-infrared (MIR/NIR) spectroscopy: A quick and sensitive method for dairy products analysis including liquid milk, infant formula, and milk powder. Talanta 2011, 85, 562-568. [CrossRef]

68. Visentin, G.; McDermott, A.; McParland, S.; Berry, D.P.; Kenny, O.; Brodkorb, A.; Fenelon, M.A.; De Marchi, M. Prediction of bovine milk technological traits from mid-infrared spectroscopy analysis in dairy cows. J. Dairy Sci. 2015, 98, 6620-6629. [CrossRef]

69. Bahadi, M.; Ismail, A.A.; Vasseur, E. Fourier Transform Infrared Spectroscopy as a Tool to Study Milk Composition Changes in Dairy Cows Attributed to Housing Modifications to Improve Animal Welfare. Foods 2021, 10, 450. [CrossRef]

70. Liu, N.; Parra, H.A.; Pustjens, A.; Hettinga, K.; Mongondry, P.; van Ruth, S.M. Evaluation of portable near-infrared spectroscopy for organic milk authentication. Talanta 2018, 184, 128-135. [CrossRef] [PubMed]

71. Delhez, P.; Ho, P.; Gengler, N.; Soyeurt, H.; Pryce, J. Diagnosing the pregnancy status of dairy cows: How useful is milk mid-infrared spectroscopy? J. Dairy Sci. 2020, 103, 3264-3274. [CrossRef] [PubMed]

72. Borin, A.; Ferrao, M.F.; Mello, C.; Maretto, D.A.; Poppi, R.J. Least-squares support vector machines and near infrared spectroscopy for quantification of common adulterants in powdered milk. Anal. Chim. Acta 2006, 579, 25-32. [CrossRef]

73. Benedet, A.; Franzoi, M.; Penasa, M.; Pellattiero, E.; De Marchi, M. Prediction of blood metabolites from milk mid-infrared spectra in early-lactation cows. J. Dairy Sci. 2019, 102, 11298-11307. [CrossRef]

74. Cecchinato, A.; De Marchi, M.; Gallo, L.; Bittante, G.; Carnier, P. Mid-infrared spectroscopy predictions as indicator traits in breeding programs for enhanced coagulation properties of milk. J. Dairy Sci. 2009, 92, 5304-5313. [CrossRef] [PubMed]

75. Coppa, M.; Martin, B.; Agabriel, C.; Chassaing, C.; Sibra, C.; Constant, I.; Graulet, B.; Andueza, D. Authentication of cow feeding and geographic origin on milk using visible and near-infrared spectroscopy. J. Dairy Sci. 2012, 95, 5544-5551. [CrossRef] [PubMed]

76. De Roos, A.; Van Den Bijgaart, H.; Hørlyk, J.; De Jong, G. Screening for subclinical ketosis in dairy cattle by Fourier transform infrared spectrometry. J. Dairy Sci. 2007, 90, 1761-1766. [CrossRef]

77. Kawasaki, M.; Kawamura, S.; Tsukahara, M.; Morita, S.; Komiya, M.; Natsuga, M. Near-infrared spectroscopic sensing system for on-line milk quality assessment in a milking robot. Comput. Electron. Agric. 2008, 63, 22-27. [CrossRef]

78. Tang, S.; Johnson, J.C.; Jarto, I.; Smith, B.; Morris, S. Milk Components by in-Line Fiber Optic Probe-Based FT-NIR: Commercial Scale Evaluation of a Potential Alternative Measurement Approach for Milk Payment. J. AOAC Int. 2020, 104, 1328-1337. [CrossRef] [PubMed]

79. Nicolaou, N.; Xu, Y.; Goodacre, R. Fourier transform infrared and Raman spectroscopies for the rapid detection, enumeration, and growth interaction of the bacteria Staphylococcus aureus and Lactococcus lactis ssp. cremoris in milk. Anal. Chem. 2011, 83, 5681-5687. [CrossRef] [PubMed]

80. Leitner, G.; Merin, U.; Krifucks, O.; Blum, S.; Rivas, A.L.; Silanikove, N. Effects of intra-mammary bacterial infection with coagulase negative staphylococci and stage of lactation on shedding of epithelial cells and infiltration of leukocytes into milk: Comparison among cows, goats and sheep. Vet. Immunol. Immunopathol. 2012, 147, 202-210. [CrossRef] [PubMed]

81. Rienesl, L.; Khayatzadeh, N.; Köck, A.; Dale, L.; Werner, A.; Grelet, C.; Gengler, N.; Auer, F.-J.; Egger-Danner, C.; Massart, X. Mastitis detection from milk mid-infrared (MIR) spectroscopy in dairy cows. Acta Univ. Agric. Silvic. Mendel. Brun. 2019, 67, 1221-1226. [CrossRef]

82. Treguier, S.; Couderc, C.; Tormo, H.; Kleiber, D.; Levasseur-Garcia, C. Identification of lactic acid bacteria Enterococcus and Lactococcus by near-infrared spectroscopy and multivariate classification. J. Microbiol. Methods 2019, 165, 105693. [CrossRef] [PubMed]

83. Cattaneo, T.M.; Holroyd, S.E. The use of near infrared spectroscopy for determination of adulteration and contamination in milk and milk powder: Updating knowledge. J. Near Infrared Spectrosc. 2013, 21, 341-349. [CrossRef]

84. Ageev, A.; Osiptsov, A. Shear Flow of a Viscous Fluid over a Cavity with a Pulsating Gas Bubble. In Proceedings of the Doklady Physics; Pleiades Publishing: New York, NY, USA, 2020; pp. 242-245.

85. Jensen, R.G.; Ferris, A.M.; Lammi-Keefe, C.J. The composition of milk fat. J. Dairy Sci. 1991, 74, 3228-3243. [CrossRef]

86. Roy, B.; Brahma, B.; Ghosh, S.; Pankaj, P.K.; Mandal, G. Evaluation of Milk Urea Concentration as Useful Indicator for Dairy Herd Management: A Review. Asian J. Anim. Vet. Adv. 2011, 6, 1-19. [CrossRef]

87. DePeters, E.J.; Ferguson, J.D. Nonprotein Nitrogen and Protein Distribution in the Milk of Cows. J. Dairy Sci. 1992, 75, 3192-3209. [CrossRef]

88. Jenness, R. Biosynthesis and composition of milk. J. Investig. Dermatol. 1974, 63, 109-118. [CrossRef] [PubMed]

89. Jenness, R. Composition of milk. In Fundamentals of Dairy Chemistry; Springer: Boston, MA, USA, 1988; pp. 1-38.

90. Etzion, Y.; Linker, R.; Cogan, U.; Shmulevich, I. Determination of protein concentration in raw milk by mid-infrared Fourier transform infrared/attenuated total reflectance spectroscopy. J. Dairy Sci. 2004, 87, 2779-2788. [CrossRef]

91. Rutten, M.J.M.; Bovenhuis, H.; Hettinga, K.A.; van Valenberg, H.J.F.; van Arendonk, J.A.M. Predicting bovine milk fat composition using infrared spectroscopy based on milk samples collected in winter and summer. J. Dairy Sci. 2009, 92, 6202-6209. [CrossRef]

92. Laporte, M.-F.; Paquin, P. Near-infrared analysis of fat, protein, and casein in cow's milk. J. Agric. Food Chem. 1999, 47, 2600-2605. [CrossRef] 
93. Purnomoadi, A.; Batajoo, K.K.; Ueda, K.; Terada, F. Influence of feed source on determination of fat and protein in milk by near-infrared spectroscopy. Int. Dairy J. 1999, 9, 447-452. [CrossRef]

94. Godden, S.; Lissemore, K.; Kelton, D.; Leslie, K.; Walton, J.; Lumsden, J. Relationships between milk urea concentrations and nutritional management, production, and economic variables in Ontario dairy herds. J. Dairy Sci. 2001, 84, 1128-1139. [CrossRef]

95. Nousiainen, J.; Shingfield, K.; Huhtanen, P. Evaluation of milk urea nitrogen as a diagnostic of protein feeding. J. Dairy Sci. 2004, 87, 386-398. [CrossRef]

96. Horrocks, R.; Vallentine, J. Forage Quality-The Basics; Acdemic Press: San Diego, CA, USA, 1999; pp. $17-47$.

97. Rego, G.; Ferrero, F.; Valledor, M.; Campo, J.C.; Forcada, S.; Royo, L.J.; Soldado, A. A portable IoT NIR spectroscopic system to analyze the quality of dairy farm forage. Comput. Electron. Agric. 2020, 175, 105578. [CrossRef]

98. Yang, Z.; Nie, G.; Pan, L.; Zhang, Y.; Huang, L.; Ma, X.; Zhang, X. Development and validation of near-infrared spectroscopy for the prediction of forage quality parameters in Lolium multiflorum. PeerJ 2017, 5, e3867. [CrossRef]

99. Jennewein, J.S.; Eitel, J.U.; Joly, K.; Long, R.A.; Maguire, A.J.; Vierling, L.A.; Weygint, W. Estimating integrated measures of forage quality for herbivores by fusing optical and structural remote sensing data. Environ. Res. Lett. 2021, 16, 075006. [CrossRef]

100. Lavin, S.R.; Sullivan, K.E.; Wooley, S.C.; Stone, K.; Russell, S.; Valdes, E.V. Near infrared reflectance spectroscopy (NIRS) analyses of nutrient composition and condensed tannin concentrations in carolina willow (Salix caroliniana). Zoo Biol. 2015, 34, 576-582. [CrossRef]

101. Marchesini, G.; Serva, L.; Garbin, E.; Mirisola, M.; Andrighetto, I. Near-infrared calibration transfer for undried whole maize plant between laboratory and on-site spectrometers. Ital. J. Anim. Sci. 2018, 17, 66-72. [CrossRef]

102. Fox, G.P.; O’Donnell, N.H.; Stewart, P.N.; Gleadow, R.M. Estimating hydrogen cyanide in forage sorghum (Sorghum bicolor) by near-infrared spectroscopy. J. Agric. Food Chem. 2012, 60, 6183-6187. [CrossRef] [PubMed]

103. Bokobza, L. Origin of Near-Infrared Absorption Bands; Wiley-VCH: Weinheim, Gemrany, 2002.

104. Auer, B.; Skinner, J. IR and Raman spectra of liquid water: Theory and interpretation. J. Chem. Phys. 2008, 128, 224511. [CrossRef] [PubMed]

105. Ikoyi, A.Y.; Younge, B.A. Influence of forage particle size and residual moisture on near infrared reflectance spectroscopy (NIRS) calibration accuracy for macro-mineral determination. Anim. Feed. Sci. Technol. 2020, 270, 114674. [CrossRef]

106. Ji, C.; Zhang, X.; Yu, P. Using non-invasive molecular spectroscopic techniques to detect unique aspects of protein Amide functional groups and chemical properties of modeled forage from different sourced-origins. Spectrochim. Acta Part A Mol. Biomol. Spectrosc. 2016, 156, 151-154. [CrossRef] [PubMed]

107. Tilley, J.; Terry, R. A two-stage technique for the in vitro digestion of forage crops. Grass Forage Sci. 1963, 18, 104-111. [CrossRef]

108. Wajizah, S.; Munawar, A.A. Near infrared spectroscopy (NIRS) data analysis for a rapid and simultaneous prediction of feed nutritive parameters. Data Brief 2020, 29, 105211. [CrossRef]

109. Zgouz, A.; Héran, D.; Barthès, B.; Bastianelli, D.; Bonnal, L.; Baeten, V.; Lurol, S.; Bonin, M.; Roger, J.-M.; Bendoula, R.; et al. Dataset of visible-near infrared handheld and micro-spectrometers-comparison of the prediction accuracy of sugarcane properties. Data Brief 2020, 31, 106013. [CrossRef]

110. Samadi, S.W.; Munawar, A. Rapid and simultaneous determination of feed nutritive values by means of near infrared spectroscopy. Trop. Anim. Sci. J 2018, 41, 121-127. [CrossRef]

111. Norman, H.C.; Hulm, E.; Humphries, A.W.; Hughes, S.J.; Vercoe, P.E. Broad near-infrared spectroscopy calibrations can predict the nutritional value of $>100$ forage species within the Australian feedbase. Anim. Prod. Sci. 2020, 60, 1111-1122. [CrossRef]

112. Acosta, J.; Castillo, M.; Hodge, G. Comparison of benchtop and handheld near-infrared spectroscopy devices to determine forage nutritive value. Crop. Sci. 2020, 60, 3410-3422. [CrossRef]

113. Baath, G.S.; Baath, H.K.; Gowda, P.H.; Thomas, J.P.; Northup, B.K.; Rao, S.C.; Singh, H. Predicting forage quality of warm-season legumes by near infrared spectroscopy coupled with machine learning techniques. Sensors 2020, 20, 867. [CrossRef] [PubMed]

114. Berzaghi, P.; Cherney, J.; Casler, M.D. Prediction performance of portable near infrared reflectance instruments using preprocessed dried, ground forage samples. Comput. Electron. Agric. 2021, 182, 106013. [CrossRef]

115. Nieto-Sierra, D.F.; Meneses-Buitrago, D.H.; Morales-Montero, S.P.; Hernández-Oviedo, F.; Castro-Rincón, E. Características productivas de cultivos forrajeros en sistemas de producción de leche, Nariño, Colombia. Agron. Mesoam. 2020, 31, 177-192. [CrossRef]

116. Wijesingha, J.; Astor, T.; Schulze-Brüninghoff, D.; Wengert, M.; Wachendorf, M. Predicting forage quality of grasslands using UAV-borne imaging spectroscopy. Remote Sens. 2020, 12, 126. [CrossRef]

117. Andueza, D.; Picard, F.; Martin-Rosset, W.; Aufrère, J. Near-infrared spectroscopy calibrations performed on oven-dried green forages for the prediction of chemical composition and nutritive value of preserved forage for ruminants. Appl. Spectrosc. 2016, 70, 1321-1327. [CrossRef]

118. Rodrigues, F.A.; Blasch, G.; Defourny, P.; Ortiz-Monasterio, J.I.; Schulthess, U.; Zarco-Tejada, P.J.; Taylor, J.A.; Gérard, B. Multitemporal and spectral analysis of high-resolution hyperspectral airborne imagery for precision agriculture: Assessment of wheat grain yield and grain protein content. Remote Sens. 2018, 10, 930. [CrossRef]

119. Serrano, J.; Shahidian, S.; Carapau, Â.; Rato, A.E. Near-Infrared Spectroscopy (NIRS) and Optical Sensors for Estimating Protein and Fiber in Dryland Mediterranean Pastures. AgriEngineering 2021, 3, 73-91. [CrossRef]

120. Lednev, V.N.; Bunkin, A.F.; Pershin, S.M.; Grishin, M.Y.; Artemova, D.G.; Zavozin, V.A.; Sdvizhenskii, P.A.; Nunes, R.A. Remote Laser Induced Fluorescence of Soils and Rocks. Photonics 2021, 8, 411. [CrossRef] 
121. Lee, H.; Kim, M.S.; Lim, H.-S.; Park, E.; Lee, W.-H.; Cho, B.-K. Detection of cucumber green mottle mosaic virus-infected watermelon seeds using a near-infrared (NIR) hyperspectral imaging system: Application to seeds of the "Sambok Honey" cultivar. Biosyst. Eng. 2016, 148, 138-147. [CrossRef]

122. Wajizah, S.; Munawar, A. Fast and simultaneous prediction of animal feed nutritive values using near infrared reflectance spectroscopy. In Proceedings of the IOP Conference Series: Earth and Environmental Science; IOP Publishing: Bristol, UK, 2018; p. 012112.

123. Cui, C.; Fearn, T. Comparison of partial least squares regression, least squares support vector machines, and Gaussian process regression for a near infrared calibration. J. Near Infrared Spectrosc. 2017, 25, 5-14. [CrossRef]

124. Agelet, L.E.; Hurburgh Jr, C.R. A tutorial on near infrared spectroscopy and its calibration. Crit. Rev. Anal. Chem. 2010, 40, 246-260. [CrossRef] 